\title{
Three-dimensional gravity and magnetic modelling of the Irish sector of the NE Atlantic margin
}

\author{
G.S. Kimbell $^{\mathrm{a}^{*}}$, J.D. Ritchie ${ }^{\mathrm{b}}$ and A.F. Henderson ${ }^{\mathrm{b}}$ \\ ${ }^{a}$ British Geological Survey, Keyworth, Nottingham, NG12 5GG, UK \\ ${ }^{b}$ British Geological Survey, Murchison House, West Mains Road, Edinburgh, EH9 3LA, UK
}

A new 3D lithospheric model has been constructed using high-resolution gravity data from the Irish National Seabed Survey. The sedimentary component of the model incorporated density variations due to laterally varying overcompaction associated with Cenozoic denudation. After optimisation based on gravity inversion, regional crustal thickness variations were defined which are in reasonable agreement with the results of wide-angle seismic experiments. High crustal extension factors $(\beta>5)$ characterise the deeper parts of the Rockall and Porcupine basins and in places the model indicates extreme stretching $(\beta>10)$ beneath these basins. This could be because of instability in the gravity inversion, although other recent investigations have independently suggested similarly high extension factors. In contrast, the Hatton Basin is characterised by an apparent extension factor of about 2. The modelling resolves a pattern of NE- to NNE-trending local Mesozoic basins on the margins of the Rockall Trough, helping to delineate structures that were previously only sparsely sampled by seismic surveys. It appears possible that rifts with similar trends underlie the volcanic rocks which obscure the deeper parts of the Hatton Basin. The linear trends of the basins to the south and east of Ireland are interpreted to have been inherited from a basement fabric that was initially established during the late Precambrian assembly of this basement and subsequently subjected to Caledonian and Variscan reactivation. Magnetic modelling indicates that the variations in the thickness of the crystalline crust predicted by the gravity models can explain the regional magnetic anomaly patterns over the Rockall and Porcupine basins, but that significant additional magnetic material (probably igneous rocks of both Palaeogene and Cretaceous ages) is required to explain the anomalies in the Hatton Basin region. The magnetic signature of the Rockall Basin is distinctly different to that over the basement (of similar apparent thickness) formed during mid Cretaceous (C34N) opening of the ocean basin to the south. This is an impediment to hypotheses that invoke mid Cretaceous sea-floor spreading rather than intracontinental rifting to explain the development of the basin. The exception is in the extreme south of the basin where the volcanism associated with the Barra Volcanic Ridges combined with indications of relatively strong lithosphere could be evidence of incipient ocean opening.

\section{* Corresponding author}

E-mail addresses: gsk@bgs.ac.uk (G.S. Kimbell), jdri@bgs.ac.uk (J.D. Ritchie), afhe@bgs.ac.uk (A.F. Henderson).

Keywords: Ireland; north-east Atlantic; continental margin; gravity modelling; magnetic modelling 


\section{Introduction}

The Irish Designated Area extends for more than $1200 \mathrm{~km}$, from the Irish Sea in the east to the continental margin adjacent to the Edoras High in the west, and contains a large number of sedimentary basins (Fig.1). Shannon et al. (2001) categorized these basins into two groups: inboard basins with predominantly pre-Cenozoic sedimentary fill and little bathymetric expression, and larger outboard basins with mainly Cenozoic and Cretaceous fill and a distinct bathymetric expression. The latter group includes the Rockall, Hatton and Porcupine basins.

The region spans the transition between the magma-poor and magma-dominated parts of the NE Atlantic margin (Reston, 2009). Northward from the Edoras High this margin is characterised by volcanic sequences imaged as seaward-dipping reflectors (SDRs) and highvelocity underplated or intruded lower crust, which have been linked to rifting under the influence of relatively high mantle temperatures associated with the Iceland Plume (White and McKenzie, 1989; Barton and White, 1997a, b). Palaeogene plateau basalts extend landward from the margin across the Hatton Basin and Rockall High. In the south (e.g. on the Goban Spur margin) seaward-dipping reflectors and underplating appear to be absent, although basaltic lava flows have been proven at DSDP Site 551 (de Graciansky et al., 1985) and are responsible for a local magnetic anomaly (Scrutton, 1985; Louvel et al., 1997).

Kimbell et al. $(2004,2005)$ presented results of regional 3D gravity modelling of the lithospheric structure of the NE Atlantic margin, which included the Irish sector. The models were constrained using isostatic and flexural principles and optimised by inversion of gravity anomalies. They define the regional pattern of crustal thickness variation along the margin and the geometries of the main sedimentary basins. The resolution was limited by a number of factors, including shortcomings in the initial model for the cover sequence and restrictions in resolution associated with the use of satellite-derived gravity data (Kimbell et al., 2004). The present paper will describe application of similar 3D modelling methods to the Irish margin, in which the resolution has been improved by adopting a more sophisticated cover sequence model and employing a gravity dataset which includes modern, high-resolution marine data collected during the Irish National Seabed Survey. 


\section{Form and evolution of the main basins on the Irish margin}

\subsection{Rockall Basin and associated marginal basins}

The Rockall Basin is the dominant structural feature within the study area and extends to the NE into UK waters (Fig. 1) (see Naylor et al., 1999). It is a NE- to NNE-trending, $1100 \mathrm{~km}$ long, mainly Mesozoic and younger, sediment-starved, deepwater rift basin which narrows from approximately $350 \mathrm{~km}$ in the south to less than $200 \mathrm{~km}$ in the north.

Within the study area, only exploration wells 5/22-1 and 12/2-1A have been drilled on the eastern flank of the basin (Fig. 1). In the latter well, gas condensate was recovered from Permian strata within a tilted fault block (P. Croker, oral communication, $6^{\text {th }}$ Petroleum Geology Conference, London, 2003). The age, distribution and thickness of the prePalaeogene stratigraphic intervals are mainly inferred from velocity data derived from the results of wide-angle seismic experiments (e.g. Keser Neish, 1993; Shannon et al., 1994; O’Reilly et al., 1995; Shannon et al., 1999; Mackenzie et al., 2002; Morewood et al., 2005). Estimates of gross stratigraphic thicknesses vary between 4.5 and $7.0 \mathrm{~km}$, with the thickest sections occurring towards the margins of the basins where inferred early Mesozoic basins are better developed (e.g. Naylor and Shannon, 2005; Mackenzie et al., 2002). There are also a number of narrow, NNE- to NE-trending, mainly Mesozoic to Late Palaeozoic remnant half-grabens developed on both flanks of the Rockall Basin (see Naylor et al., 1999), the most important of which are the contiguous NNE-trending Slyne and NE-trending Erris basins on the eastern margin of the basin. The Slyne Basin has been drilled by a number of wells including 27/5-1 and 13-1 in the south and 18/20-1, 2, 3 and 4 associated with the Corrib Field in the north (Fig. 1). The basin is considered to be a mainly Triassic-Jurassic halfgraben, with the most significant phase of rifting occurring during mid Jurassic times (Dancer et al., 2005). It is interpreted to contain a thin Cenozoic-Cretaceous succession overlying 2.5 $\mathrm{km}$ of Middle Jurassic and also Permo-Triassic and Carboniferous (Westphalian) strata (Dancer et al., 1999). The Slyne Basin is separated from the Erris Basin to the north by a NW-trending transfer zone (Dancer et al., 1999). The Erris Basin has been drilled by wells 19/5-1 and 12/13-1A (Fig. 1) and is considered to comprise a series of sub-basins that were formed during phases of Permo-Triassic and late Middle to Upper Jurassic rifting (Chapman et al., 1999). According to Chapman et al. (1999), the basin contains Cenozoic, Jurassic and Permo-Triassic successions with a maximum stratigraphic thickness of approximately $6 \mathrm{~km}$. 
In the Irish sector of the Rockall Basin, extension factors of $\beta=4$ to 6 have been reported by Shannon et al. (1999) from the RAPIDS seismic experiment, though they prefer a depthdependent stretching model with values varying between $\beta=9$ in the upper/middle crust and $\beta=4$ in the lower crust (see also Morewood et al., 2005). The crystalline crust is approximately $6 \mathrm{~km}$ thick, with the Moho interpreted to lie at a depth of $14 \mathrm{~km}$ and the thinnest crust occurring towards the margins of the basin (Keser Neish, 1993; Hauser et al., 1995; O’Reilly et al., 1995; Mackenzie et al., 2002, Morewood et al., 2005).

There is still great uncertainty regarding the timing and number of phases of rifting associated with the formation of the Rockall Basin, partly due to a lack of wells to calibrate its infill. The suggestions include: Early Cretaceous (e.g. Musgrove and Mitchener, 1996); Late Cretaceous (Hanisch, 1984); Permo-Triassic, Jurassic and Early Cretaceous (Knott et al., 1993); Cretaceous to Cenozoic but with older pre-Cretaceous phases (e.g. Nadin et al., 1999); Neocomian (Scrutton and Bentley, 1988); Jurassic-Early Cretaceous (Corfield et al., 1999); Jurassic-Cretaceous (Mackenzie et al., 2002); Triassic to Late Jurassic-Cretaceous (Shannon et al., 1999); Latest Triassic-Cretaceous (Roberts et al., 1999); Permo-Triassic to Jurassic (Shannon et al., 1994); Permo-Triassic, Late Jurassic and localised Early Cretaceous (Naylor and Shannon, 2005); Permo-Triassic (Bott and Watts, 1971); and Carboniferous (e.g. Haszeldine and Russell, 1987).

There has also been much debate regarding the nature of the basement that floors the Rockall Basin with suggestions including: oceanic crust, formed during Jurassic-Lower Cretaceous (e.g. Roberts, 1975), Mid-Late Cretaceous (Kristofferson, 1978; Chappell and Kusznir, 2005), Early Permian (Russell and Smythe, 1978) or Late Carboniferous (Haszeldine and Russell, 1987) times; quasi-oceanic crust formed during Late Carboniferous-Early Permian (Smythe, 1989) times; stretched continental crust with zones of oceanic crust (e.g. Megson, 1987); highly stretched continental crust (Shannon et al., 1994, 1999; Hauser et al., 1995; O'Reilly et al., 1996; Morewood et al., 2005); highly stretched continental crust with concomitant igneous intrusion (Joppen and White, 1990); and crustal blocks interspersed with serpentinised mantle (Pérez-Gussinyé et al., 2001).

\subsection{Porcupine Basin}

The Porcupine Basin (including the North Porcupine and Seabight basins) forms a N-trending rift graben approximately $400 \mathrm{~km}$ in length, and tapering from $150 \mathrm{~km}$ width in the south to $50 \mathrm{~km}$ in the north (Fig. 1; Naylor et al., 2002, enclosure 1). The results of wide-angle 
seismic and potential field modelling indicate that its sedimentary infill is underlain by either very thin continental crust (e.g. Conroy and Brock, 1989; Johnson et al., 2001) or partially serpentinised upper mantle (Reston et al., 2004; O'Reilly et al., 2006). The basin has been drilled by approximately 30 exploration wells (see Croker and Shannon, 1987), mainly along its northern flanks and is considered to contain in excess of $8 \mathrm{~km}$ of Permo-Triassic to Recent strata, overlying a Carboniferous and Devonian succession of uncertain distribution and thickness (Naylor et al., 2002; Readman et al., 2005). The main phases of rifting are interpreted to have occurred during Permo-Triassic, Jurassic and earliest Cretaceous times (e.g. Naylor et al., 2002; Naylor and Shannon, 2005). The axial region of the central and northern parts of the Porcupine Basin is transected by a combination of the arcuate, deeply buried Porcupine Volcanic Ridge System and the N-trending Porcupine Arch (Naylor et al., 2002, enclosure 1). The ridge system is considered by Tate and Dobson (1988) to represent an igneous complex of mainly Cretaceous age, although Reston et al. (2001) prefer a serpentinite diapiric origin. The Porcupine Arch is a high-amplitude reflector which may mark the top of the crystalline basement (Johnson et al., 2001) or partially serpentinized mantle (Reston et al., 2004).

\subsection{Hatton Basin}

The Hatton Basin is approximately $500 \mathrm{~km}$ long and $200 \mathrm{~km}$ wide and extends northeastwards from the western part of the study area into UK waters (Fig. 1). It has informally been divided into northern and southern parts, separated by the WNW-trending South Hatton Lineament of Kimbell et al., 2005 (Fig. 4) The basin is one of the most poorly understood of the major basins in the NE Atlantic region, due to the masking effects of thick PaleoceneEocene volcanic and intrusive rocks (e.g. Hitchen, 2004).

The eastern margin of the Hatton Basin has been drilled by DSDP wells 116 and 117 (Fig. 1), proving approximately $850 \mathrm{~m}$ of sediments ranging from Upper Paleocene to Recent. Results from the RAPIDS wide-angle seismic experiment indicated that the Hatton Basin contains 1$2.5 \mathrm{~km}$ of Cenozoic sediments overlying up to $3.5 \mathrm{~km}$ of older high-velocity syn-rift sediments (Vogt et al., 1998). Shannon et al. (1999, their fig. 2) modified this interpretation, suggesting that approximately $1 \mathrm{~km}$ of Cenozoic sediments rest on $3 \mathrm{~km}$ of Upper Carboniferous, Permo-Triassic to Jurassic strata. On the UK Hatton margin, mid-Cretaceous sediments have been proven in shallow boreholes (Hitchen, 2004). Results from wide-angle and normal incidence profiles acquired by the iSIMM project have been interpreted to show that the basin contains approximately $2 \mathrm{~km}$ of Cenozoic post-rift sediments resting on a $2-4$ 
$\mathrm{km}$ thick, higher velocity $(4.3-6.1 \mathrm{~km} / \mathrm{s})$ layer (Smith et al., 2005; Smith, 2006). The 'hummocky' nature of the upper surface of the lower layer (e.g. Smith et al., 2005, their fig. 5) suggests that it is capped by Palaeogene volcanic rocks extruded in a submarine environment, contrasting with the parallel-bedded seismic facies of the subaerial lavas on the surrounding highs (Boldreel and Andersen, 1994). Results from the RAPIDS, iSIMM and potential field modelling studies have suggested thicknesses for the crystalline crust beneath the Hatton Basin of between 10 and 20 km (Shannon et al., 1999; Kimbell et al., 2005; Smith et al., 2005; Smith, 2006).

\section{Construction of a cover sequence model}

\subsection{Rock physical properties}

Density and sonic velocity variations within the cover sequence were investigated using geophysical logs from 28 released wells on the Irish Continental Shelf, together with log and sample measurements from Deep Sea Drilling Programme (DSDP) and Ocean Drilling Programme (ODP) sites in the region. The primary aim was to establish densities for gravity modelling, but rock sonic velocities were also analysed, both for comparison with the trends observed in the density data and to assist with the time-to-depth conversion of seismic interpretations. The densities and velocities of sedimentary rocks are influenced by both lithology and compaction. If part of a sedimentary sequence has been removed, for example by uplift and erosion, the remaining rocks will not lie at their maximum burial depth and will have higher densities and velocities than similar, but normally compacted, lithologies at the same depths. This is an important consideration on the NE Atlantic margin where there is abundant evidence of Cenozoic uplift and denudation (Doré et al., 2002a and references therein). Denudation appears to have occurred across much of the Irish continental shelf, except in the central parts of the Rockall and Porcupine basins (Allen et al., 2002; Doré et al., 2002b).

Log sections were identified that were assumed to be normally compacted on the basis of previous studies of their thermal history and the absence of unconformities. Density logs from these suggested that the shale compaction curve of Sclater and Christie (1980) would provide an appropriate 'normally compacted' reference against which to compare the other density logs. In a similar fashion, an empirical normally compacted velocity-depth relationship was established from analysis of the borehole sonic data. The geophysical well logs were then separated into Cenozoic and pre-Cenozoic components and the depth shift 
required to provide the best fit between the log data and the normal compaction trend was calculated. The velocity and density data from the pre-Cenozoic sedimentary rocks indicate denudation values that are broadly comparable with each other and with published data including other velocity analyses and appatite fission track and vitrinite reflectance data (e.g. Hillis, 1995; Murdoch et al., 1995). The denudation estimates for the Cenozoic rocks were consistently much lower than those for the pre-Cenozoic section, as expected from the uplift history of this margin.

From this evidence, a density model for the sedimentary part of the cover sequence was developed which was based on the shale compaction curve of Sclater and Christie (1980) and assumed normal compaction for the Cenozoic sedimentary strata and a varying degree of overcompaction for the pre-Cenozoic strata. There were insufficient data to map local overcompaction variations (e.g. due to inversion of individual structures), so a highly simplified denudation map was constructed (Fig. 2d) in which the shelf areas around Ireland were assigned values of $1-1.2 \mathrm{~km}$ and the sequences in the deep water basins were assumed to be normally compacted. The density of the sub-lava sedimentary rocks in the HattonRockall area is difficult to quantify, but limited apatite fission track (Hitchen, 2004) and seismic velocity (Vogt et al., 1998) data suggest that this part of the cover sequence is overcompacted. An average denudation similar to that in the shelf areas around Ireland has therefore been assumed, although it is recognised that this is poorly constrained.

The density of the basaltic lavas present in the NW of the study area was estimated using a nominal trend constructed by interpolating between the averaged values identified from density logs through thick volcanic sections on the Vøring (DSDP Site 642) and East Greenland (ODP Site 917) margins and the deeper density data available from the Lopra borehole on the Faroe Islands (Ellis et al., 2002).

\subsection{Cover sequence thickness}

An initial structural model for the cover sequence was required in order to guide the way in which the crustal contribution to observed gravity anomalies was partitioned between sedimentary and crystalline components. It is not feasible to attempt such a partition solely on the basis of gravity anomalies as it is not possible to separate the effects of long wavelength variations in sediment thickness from those due to changes in Moho depth. The structural model was constructed from a range of sources, including:

1. Composite logs from released wells. 
2. Thicknesses in two-way travel time (twtt) derived from geological cross-sections in enclosures within the structural nomenclature reports for the Irish Rockall Basin region (Naylor et al., 1999) and Porcupine-Goban region (Naylor et al., 2002).

3. Contours (in depth and twtt) from the Rockall and Porcupine basins based on unpublished maps supplied by the Irish Petroleum Affairs Division.

4. Models for the structure of the cover sequence beneath the Rockall Basin derived from wide-angle data (Joppen and White, 1990; Hauser et al., 1995; Shannon et al., 1999; Mackenzie et al., 2002; Morewood et al., 2005).

5. Contours of total sediment thickness from the North Atlantic geophysical atlas of Srivastava et al. (1988).

6. Contours of depth to acoustic basement in the Hatton-Rockall area from Roberts et al. (1979; their fig. 8).

7. Contours of total sediment thickness within the Goban Spur area (Masson et al., 1985).

8. Contours of total sediment thickness within the Celtic Sea basins area (Tucker and Arter, 1987).

9. Grids of total sediment thickness over the North Atlantic region generated by Louden et al. (2004).

10. Published seismic cross-sections (in twtt) and other data from the Peel, Kish Bank, Central Irish Sea, St Georges Channel, North Celtic Sea, Rockall, Slyne and Erris basins (e.g. Croker, 1995; Dancer et al., 1999; Dunford et al., 2001; Chapman et al., 1999; Floodpage et al., 2001; Izatt et al., 2001; Murdoch et al., 1995; Mackenzie et al., 2002)

11. Seismic interpretation from the western approaches to the English Channel from Evans et al. (1990).

12. Seismic interpretation from the Malin-Hebrides Sea area from Fyfe et al. (1993).

13. Seismic interpretation from the Isle of Man area from Chadwick et al. (2001).

The sedimentary part of the cover sequence model was divided into Cenozoic and preCenozoic components (Figs. $2 \mathrm{~b}$ and $3 \mathrm{a}$ ). Data that were only available in two-way travel time were converted to thickness using an algorithm derived from the empirical velocity-depth relationship for normally compacted sediments described in the preceding section. An overcompaction correction based on Fig. 2d was applied in the depth coversion of the preCenozoic component.

In the NW part of the study area the seismic expression of underlying sedimentary rocks is largely masked by the extensive Palaeogene lavas, such that the acoustic basement used in 
the construction of published sediment thickness maps for this area (e.g. Roberts et al., 1979; Srivastava et al., 1988) will typically lie at the top of the lavas. The initial 'Cenozoic' sedimentary model therefore nominally represents post-lava sediments in this area and the full Cenozoic sequence elsewhere.

Little information was available on the thickness of the Palaeogene lavas in the Hatton Rockall area, apart from some speculative base lava picks on seismic sections (e.g. Boldreel and Andersen, 1994), evidence for 'windows' where they are highly thinned or absent (Hitchen, 2004) and imaging of the seaward-dipping reflector sequence adjacent to the continental margin (Barton and White, 1997a, b). Only a highly simplified representation of this unit was therefore possible (Fig. 2c). This included a thickened sequence where seawarddipping reflectors were assumed to lie on continental crust (the inner reflector package of Barton and White, 1997a, b), feather-edges at the assumed limit of the lavas and where windows have been identified, and approximately $1 \mathrm{~km}$ of lavas elsewhere.

A nominal sub-lava sedimentary thickness of up to about $2 \mathrm{~km}$ was included in the Hatton Basin on the basis of the limited information available from wide-angle seismic experiments (e.g. Vogt et al., 1998). Such experiments suggest that rapid thickness variations may occur within this layer but these could not be defined a priori so a smoothly varying initial thickness was adopted with the aim of using the gravity data to resolve shorter wavelength variation.

The initial model of the base of the cover sequence does not coincide with a particular stratigraphic level, and this is even more the case after the surface has been optimised using gravity anomalies (see below). The density contrast associated with this surface is primarily that between the Mesozoic sequence and the Lower Palaeozoic and older basement. The Carboniferous strata are not easy to incorporate as their structure is poorly defined, and thus cannot generally be included in the starting model, and their properties span from those of the cover (in low density Upper Carboniferous units) to those of the basement. The optimised model may thus contain features relating to variations in the thickness of the Carboniferous sequence but these are unlikely to be simulated accurately.

\section{Geophysical modelling}

The lithospheric models comprised a series of regular grids with a $2 \mathrm{~km}$ node separation representing the depths to a set of interfaces and the lateral variations in rock densities between these interfaces. The density of the cover sequence was guided by the compaction 
and denudation trends discussed above and that of the crystalline crust was assigned representative values of $2.75 \mathrm{Mg} / \mathrm{m}^{3}$ in the upper crust and $2.95 \mathrm{Mg} / \mathrm{m}^{3}$ in the lower crust. Upper mantle densities were simulated in a way which accounted for thermal influences, as described below.

\subsection{Thermal modelling}

O'Reilly et al. (1998), Breivik et al (1999) and Kimbell et al. (2004) have demonstrated the need for incorporating thermal effects when modelling gravity anomalies in the vicinity of continental margins. In the present model, a temperature profile was calculated at each oceanic node using a 1D plate cooling model together with the estimated age of the ocean crust (Fig. 1) and the present-day bathymetry (Fig 2a). For the continental upper mantle, the temperature profile was based on a nominal geotherm calculated on the basis of a surface heat flow of $55 \mathrm{~mW} / \mathrm{m}^{2}$. Two-dimensional finite-element modelling was conducted using the THERMIC program (Bonneville \& Capolsini, 1999) and a procedure similar to that of Breivik et al. (1999) to simulate temperature variations across a continent ocean boundary formed at ages ranging from $55 \mathrm{Ma}$ to $105 \mathrm{Ma}$. The models indicated that there is a relatively pronounced thermal contrast where ocean opening has occurred most recently, but that this has largely decayed beneath the older margin. Sections taken through the thermal models indicated that the lateral temperature variations across the margin could be simulated in the 3D model with sufficient accuracy by a $170 \mathrm{~km}$ wide linear ramp centred at the continentocean boundary. The position of this boundary was derived using the methods described by Kimbell et al. (2005). The resulting upper mantle temperature model was translated into densities within a series of arbitrary 'layers' by applying corrections for thermal expansion and overburden stress, as described by Kimbell et al. (2004). It was assumed that conductive cooling extends down to the $1100^{\circ} \mathrm{C}$ isotherm and that more efficient convective heat transfer below this isotherm substantially reduces thermal gradients (see discussion in Kimbell et al., 2004).

It is recognised that the region will contain some thermal perturbations that are not simulated in the initial model. The thermal impact of Late Jurassic - Early Cretaceous continental extension should have decayed by now but any more recent extensional episodes, for example affecting the Hatton Basin, may still have a thermal imprint. The conditions that gave rise to widespread Palaeogene igneous activity on the Atlantic margin may have left a more extensive thermal effect than the 'standard' passive margin model that has been 
assumed, although 2D modelling indicates that the heat stored in the lavas and underplating will have largely dissipated by now. The uniform continental geotherm model does not allow for local perturbations in upper mantle temperatures due to variations in the thickness and thermal properties of the overlying crust.

\subsection{Construction of an optimised 3D model}

The 3D lithospheric model was constructed and optimised using the procedure described below. Potential field computations and inversions were undertaken using the BGS Gmod and Bmod programs (Dabek and Williamson, 1999) which employ wavenumber domain routines developed by Parker (1972) and Oldenburg (1974).

1. An isostatic model was constructed using topographic data and the models for mantle density variations and cover sequence structure and density described above. The post-lava sediments were represented by a series of seabed-parallel layers in order to simulate compaction effects. At this stage the pre-lava sedimentary layer was represented by a single layer with an averaged density at each node. An average density for the crystalline crust of $2.85 \mathrm{Mg} / \mathrm{m}^{3}$ was assumed, together with a reference Moho depth of $30 \mathrm{~km}$ (i.e. its nominal depth when the topographic surface lies at datum and no cover sequence is present). The Moho depth was adjusted to equalise the load at a compensation depth of $125 \mathrm{~km}$.

2. The gravity field over the entire model (down to $125 \mathrm{~km}$ ) was computed. Following Kimbell et al. (2004), the average offset between the computed field over this isostatic model and the observed field was used to define a 'background' value which was subtracted from observed gravity anomalies prior to model optimisation. In this case a shift of -15 mGal was applied to the observed anomalies. The 'indirect effect' (Chapman and Bodine, 1979), which is the gravity correction due to the difference in elevation between the geoid (the datum to which the gravity measurements are referred) and the spheroid (the datum to which the gravity reference field is referred) was effectively incorporated in this correction rather than being defined explicitly. Relative gravity variations due to the indirect effect are less than about $4 \mathrm{mGal}$ over the entire study area and less than $2.5 \mathrm{mGal}$ over the Irish Designated Area.

3. The geometry of the Moho interface was optimised by gravity inversion to improve the fit with observed longer wavelength gravity anomalies (employing a low-pass filter with a ramp between wavelengths of $67 \mathrm{~km}$ and $100 \mathrm{~km}$ ). Prior to this it was smoothed to suppress shorter 
wavelength variations resulting from its derivation on the basis of local isostasy but not detectable at Moho depths using gravity data.

4. The base sediment interface was optimised to accommodate shorter wavelength gravity variations, although it was still necessary to apply a low-pass filter (ramp between $10 \mathrm{~km}$ and $20 \mathrm{~km}$ ) to avoid instability and suppress features that might be associated with noise in the observed data.

5. The density structure of the sedimentary components and the upper mantle was recomputed using these modified interfaces. At this stage the pre-Cenozoic sedimentary unit was subdivided (in a similar fashion to the Cenozoic sediments) to provide a better representation of compaction effects. A mid-crustal interface was introduced which equally divided the crystalline crust into upper $\left(2.75 \mathrm{Mg} / \mathrm{m}^{3}\right)$ and lower $\left(2.95 \mathrm{Mg} / \mathrm{m}^{3}\right)$ components.

6. A further optimisation of the Moho interface was undertaken, using the same filter settings as in step 3. The change in Moho depth was re-scaled to reflect the movement in the midcrustal interface which was applied subsequently.

7. A further optimisation of the base sediment interface was undertaken, and the depth changes scaled at each grid node by a factor reflecting the ratio between the local contrast at this boundary and the average contrast between the pre-Cenozoic sedimentary unit and the crystalline crust.

8. The sedimentary and upper mantle densities were recomputed and a final forward gravity calculation was made using the complete model.

Figure 3 shows the thickness variations in the pre-Cenozoic sedimentary rocks before and after the optimisation process. Fig. 4 shows the total cover sequence thickness (with annotations) and Fig. 5 shows the thickness of crystalline crust and depth to Moho in the final model. The modelled gravity field matches the main features of the observed field well (Fig. 6), with the largest amplitude discrepancies occurring over igneous centres (which were not explicitly modelled). The root mean square residual gravity anomaly over the final model is $1.92 \mathrm{mGal}$.

\section{Results}

\subsection{Overview of gravity modelling results}


On a broad scale, the optimised model confirms the well-known structural configuration of the continental part of the region, with highly stretched crystalline crust and shallow Moho beneath the Rockall and Porcupine basins and more normal crustal thickness elsewhere (Fig. 5). At least some of the areas of extreme crustal thinning indicated by the model (Fig. 5a) may be artefacts due to instability in the inversion and limitations of the modelling assumptions, but the potential for continental crust to have been stretched 'to the limit' cannot be dismissed. Some recent models invoke unroofing of the mantle lithosphere beneath the Porcupine Basin (Reston et al., 2004; Readman et al., 2005) and possibly also the Rockall Basin (Pérez-Gussinyé et al., 2001). The crust beneath the deeper parts of the Hatton Basin is typically 13-16 km thick (Fig. 5a), suggesting an extension factor of around 2, significantly less than the Rockall and Porcupine basins.

The optimised model provides a more detailed picture of the structure of the cover sequence (Figs. 3 and 4) than previous regional 3D modelling (Kimbell et al., 2004, 2005). This is mainly because of a more detailed approach to the structure and properties of the initial cover sequence model and the higher resolution of the gravity field available for this study, as a result of incorporation of marine data from the Irish National Seabed Survey. The details of the small basins on the flanks of the Rockall Basin are better resolved than previously and a significantly more complex model for the structure of the Hatton Basin has been produced. The inferred structure for the pre-Cenozoic sedimentary rocks includes linear zones where there are sharp thickness changes implying fault control. Compare, for example, the initial and optimised geometries for the Slyne and Erris basins and eastern margin of the Porcupine Basin (Fig. 3a, b).

The oceanic crust is thicker in the NW corner of the study area than beneath the Porcupine Abyssal Plain in the south (Fig. 5a). This reflects the volcanic nature of the Hatton margin, where generation of thicker than normal oceanic crust has been ascribed to the influence of the Iceland Plume (White and McKenzie, 1989). The East Thulean Rise (ETR in Fig. 5) appears as a zone of thickened oceanic crust to the south of the Charlie Gibbs fracture zone, centred at about $21^{\circ} \mathrm{W} 51^{\circ} \mathrm{N}$. This feature (and the conjugate West Thulean Rise in the NW Atlantic) developed at c. $55 \mathrm{Ma}$ (magnetic chron C24R), strongly suggesting an association with a southward extension of the thermal anomaly at the time the northern Atlantic started opening between NW Europe and Greenland. It is possible to calibrate the development and decay of the thermal anomaly across the East Thulean Rise because oceanic crust lies on both sides of the feature. On the basis of the modelled crustal thickness variations, the anomaly 
appears to have developed rapidly (over a period of c. $2 \mathrm{Ma}$ ) but decayed over a longer timescale.

\subsection{Comparison with deep seismic experiments}

An obvious difference between the 3D gravity model and seismic models is that the crystalline crust in the former is arbitrarily divided into two layers of equal thickness whereas the latter are able to resolve the velocity discontinuities and often indicate a three-layer crust (e.g. Shannon et al., 1999; Mackenzie et al., 2002). Such layering cannot be resolved from gravity data and the mid-crustal interface is used as a mechanism for handling the transition from the density contrast at the base of the cover to that at the Moho, without introducing undue complexity into the models. The results should still be comparable, in terms of crustal thickness and depth to Moho, provided the average density assumed for the crystalline crust remains valid.

The Moho was modelled relative to an empirically-defined reference value of $30 \mathrm{~km}$. This provides reasonable agreement with the results of deep seismic experiments in the region, with model and seismic Mohos typically lying within about $2 \mathrm{~km}$ of each other. The shapes of Moho features are also generally well reproduced, for example along the RAPIDS 33 profile where there is asymmetrical crustal thinning across the Rockall Basin, with a steeper flank to the SE than to the NW (Fig. 7). The agreement in Moho depth beneath the Rockall Basin is perhaps surprising, given the evidence for a relatively low seismic velocity in the upper mantle beneath the basin, which has been interpreted as the result of serpentinisation (O'Reilly et al., 1996; Morewood et al., 2005). This potential low density zone is not incorporated in the model and thus might be expected to result in the model Moho lying at greater depth than the seismic Moho (Kimbell et al., 2004). It may be that the density effect of serpentinisation is offset by a thermal effect (relatively cold upper mantle because of thinning and reduced heat production in the overlying crust).

The model appears to underestimate the thickness of oceanic crust beneath the Porcupine Abyssal Plain in the SW. White (1992) tabulates results from 7 seismic soundings around the Goban-Western Approaches margin that indicate an average seismic thickness for the crystalline crust of $6.37 \mathrm{~km}$ while the average modelled crustal thickness at the same sites is $5.23 \mathrm{~km}$. There is little seismic evidence for the thickness of the oceanic crust further to the west, away from the continental margin, but the comparisons described above suggest that the typical modelled thickness of 3-4 km in this area (Figure 5a) is an underestimate. This 
could arise in part because the density of the oceanic crust is underestimated, but inaccuracies in other modelling assumptions (reference model and background field) may also be involved. There may be lateral changes in mantle density due to varying degrees of mantle depletion which are not allowed for in the modelling. The oceanic crust in this region nonetheless still appears to be thinner than the global average of about $7 \mathrm{~km}$, as Thinon et al. (2003) cite values of 3-5 $\mathrm{km}$ for the oceanic crust off the North Armorican margin to the south. Bullock and Minshull (2005) suggest that exhumed mantle may be present in a c. 70 $\mathrm{km}$ wide zone adjacent to the continent-ocean boundary at the Goban Spur margin (see further discussion in Section 6).

\subsection{Discussion of selected features}

Selected features of the cover sequence model are annotated in Fig. 4 and discussed below using the same abbreviations.

\subsubsection{Hatton Ridge basins}

Inboard of the seaward-dipping reflectors on the Hatton Margin (SDR in Fig. 4) are the Hatton Ridge basins (HRB), which have northern and southern parts separated by a possible transfer structure termed the South Hatton Lineament (SHL) by Kimbell et al. (2005). Seismic evidence for an offset in the post-lava components of these basins is provided by Roberts et al. (1979). The southern basin has been drilled at DSDP Site 555, which demonstrates the post-lava sedimentary thickening, and the gravity modelling suggests that a pre-lava component is also required. Seismic evidence for pre-lava structure is very limited, but there is a weak indication of dipping reflections from a sub-lava sequence in the northern basin on line CDP87-3 of Keser Neish (1993, her fig. 9, SP45300).

\subsubsection{Hatton Basin}

The model for the deep structure of the Hatton Basin is speculative, because of very limited control. The post-lava sedimentary model is based on only limited data and there is little control over the thickness of the lavas and pre-lava sediments. Errors in the initial top lava surface will have been absorbed (and amplified) by artefacts in the modelled base of the cover sequence. The model nonetheless is interpreted to provide at least some qualitative insight into the structural fabric of the basin.

The cover sequence has a modelled thickness of up to about $6 \mathrm{~km}$ in the northern part of the Hatton Basin (NHB), with the thickest deposits lying along an ENE-trending axis. Smith et 
al. (2005) estimated a total cover sequence thickness within the basin of about $4 \mathrm{~km}$ beneath the iSIMM seismic profile, which lies just to the north of the present study area and this is compatible with the adjacent parts of our model. Smith (2006) revised this interpretation to include up to about $7 \mathrm{~km}$ of cover, but with relatively high $(>5 \mathrm{~km} / \mathrm{s})$ velocities in its lower part. It is likely that the basin contains pre-Cenozoic sedimentary rocks at depth. These have not yet been clearly imaged by seismic reflection surveys but there is evidence of deformed strata beneath the lavas on the Hatton High (Keser Neish, 1993; Hitchen, 2004) and boreholes proving mid-Cretaceous sedimentary rocks in this area (Hitchen, 2004).

There is a change in the modelled structural fabric of the Hatton Basin across the South Hatton Lineament, with the southern part of basin (SHB) characterised by a series of highs and lows with a NNE trend (Fig. 4). Although some of the modelled structure at the base of the cover sequence may be an artefact due to shortcomings in the resolution of interfaces at shallower levels (e.g. top lava), there is seismic evidence from RAPIDS (Vogt et al., 1998) and GEUS (Boldreel and Andersen, 1994; Edwards, 2002) profiles for rapid variations in the thickness of a lower sedimentary layer, compatible with the configuration of the 3D model. The trend of the structures inferred from the gravity model matches that of Mesozoic structures elsewhere in the study area.

\subsubsection{Basins on the Rockall High}

Naylor et al. (1999) identified the Colmán (COLB) and Ciarán (CIAB) basins at the southern end of the Rockall High from their expressions on a single seismic line, but were not able to define their lateral extent because of lack of data. They considered it likely that both were Mesozoic basins. The 3D model suggests that the Colmán Basin is a linear feature about 90 km long (Fig.4). The modelled northern margin of the Ciarán Basin has an E-W orientation while a basement high on its south-eastern side has a NW trend.

The model indicates two further basins on the Rockall High further to the NE. The form of the gravity anomaly over the western of these (R1) suggests that it is a half-graben which is faulted on its SE side. Naylor et al. (1999) mapped a fault which coincides with this margin but did not detect significant sedimentary infill, perhaps because this fill is of Mesozoic age and masked by Palaeogene lavas. The second, more northerly basin (R2) appears as an uppercrustal, low velocity zone at the NW end of the RAPIDS 33 profile (Figs. 4, 7); Mackenzie et al. (2002) ascribe the velocity effect to fractured or weathered basement rather than a sedimentary depocentre but the gravity signature favours the latter explanation. 
The modelled forms of the Conall (CNB) and Rónán (ROB) basins are similar to those mapped by Naylor et al. (1999), although the Conall Basin has a somewhat more arcuate shape. A further basin (R3 in Fig. 4) is modelled on the Rockall High just north of the median line. It has a similar trend to the Rónán Basin and may thus be a faulted Mesozoic basin beneath the Palaeogene basalts. Hitchen (2004) reports evidence for natural oil seeps along the NW margin of this basin and a separate set which align along a prolongation of the NW margin of the Rónán Basin to the south. There are further possible small basins to the $\mathrm{E}$ and NE of R3 at the edge of the Rockall Basin although these are not well resolved because of limitations in the bathymetric and gravity data coverage.

\subsubsection{Rockall Basin}

The modelled average thickness of the crystalline crust beneath the Rockall Basin is 5-6 km but there is a distinct increase in crustal thickness in the north, with values of around $10 \mathrm{~km}$ characterising the part of the basin to the north of the Irish Designated Area (Fig. 5a). Wideangle seismic experiments (Roberts et al., 1988; Klingelhöfer et al., 2005) and previous gravity modelling (Kimbell et al., 2005) confirm that lower apparent extension factors characterise the Rockall Basin to the north of the present study area, with the change in degree of extension probably accommodated by transfer movements on the intervening Anton Dohrn lineament zone (Kimbell et al., 2005). Gravity and seismic data suggest that the crystalline crust beneath the axis of the northern part of the Irish Rockall Basin is somewhat thicker than towards its flanks, and O'Reilly et al. (1995) have ascribed this to cooling and strengthening along this axis leading to outward migration of strain to the warmer margins (see also Bassi, 1995).

The Barra Volcanic Ridge System (Fig. 1) in the southern part of the Rockall Basin comprises a series of arcuate ridges in the acoustic basement which are associated with strong magnetic anomalies (Fig. 8a; Bentley and Scrutton, 1987; Scrutton and Bentley, 1988). The ridges are considered to be extrusive volcanic edifices which were subsequently draped with sedimentary rocks until finally being overstepped by sediment in Eocene time (Scrutton and Bentley, 1988). The stratigraphic control does not allow them to be dated accurately but they may be of Early Cretaceous age, when there was also significant igneous activity in the Porcupine Basin and on the Labrador Margin (Scrutton and Bentley, 1988; Tate and Dobson, 1988; Balkwill, 1987; DeSilva, 1999). Although the seismically-imaged ridges appear extrusive, modelling by Scrutton and Bentley (1988) indicated that the magnetic anomalies 
are best explained by a combination of the extrusive units and underlying intrusions, presumably lying along the fissures through which the igneous rocks were emplaced. The two most prominent ridges (in terms of their magnetic anomalies) correlate closely with the margins of a pronounced positive gravity anomaly ( $\mathrm{GH}$ in Fig. 6a). This is accommodated in the 3D model by a zone of highly stretched crystalline crust, although a lateral change in crustal density provides an alternative explanation (Scrutton and Bentley, 1988). In either case there is a requirement for a marked departure from isostatic equilibrium, indicating significant lithospheric strength.

\subsubsection{Basins on the SE side of the Rockall Basin}

The North Bróna Basin (NBB) and South Bróna Basin (SBB) are Mesozoic basins on the western side of the Porcupine High and the Cillian Basin (CB) is a shallow graben lying on their east side (Figs. 1 and 4). Naylor et al. (1999) ascribe a Cenozoic age to the Cillian Basin, but Haughton et al. (2005) indicate that it may contain a substantial proportion of Cretaceous sediments. The southern part of the Cillian Basin is not well resolved by the 3D model, but the results do suggest that it extends about $30 \mathrm{~km}$ further to the NW than is indicated in the map of Naylor et al. (1999) (Figs. 1 and 4). The ENE alignment of the northern margin of this extension suggests the possibility of influence by reactivated Caledonian structures (Great Glen Fault or Fair Head - Clew Bay Line).

The model indicates a further possible basin on the Porcupine High (PHB) between the Cillian and Macdara basins. Corfield et al. (1999) interpreted this to lie between splays of the Great Glen Fault. The interpretation by Naylor et al. (1999) of GSI Line 1 indicates only thin Cenozoic cover across the basin, suggesting a Mesozoic or older age. Recent evidence for lavas of Cretaceous age in this area (Haughton et al., 2005) might explain the difficulty in imaging deeper structure on seismic profiles.

The model emphasises the linearity of the Erris Basin (EB), and comparison with the starting model reveals that the most strongly linear components were introduced by the gravity optimisation and thus provide an independent view of the fault architecture. The northern extension of the basin is offset north of $55.8^{\circ} \mathrm{N}$ and the southern limit of the basin occurs in an area of structural complexity at its intersection with the Slyne Basin. The gravity and magnetic modelling enable the Erris High (EH) to be traced over a distance of about $170 \mathrm{~km}$, linking it southward to a basement high detected on WESTLINE (England and Hobbs, 1997). 
The Slyne Basin (SB) is another strongly linear feature, particularly along its faulted western margin, and this accentuates the difference between its NNE trend and the NE trend of the Erris Basin. The eastern margin of the basin appears faulted towards the north, close to the intersection with the Erris Basin, but more diffuse south of about $54^{\circ} \mathrm{N}$, where the main fault is modelled to lie on the west side of the basin. This is compatible with the seismic images presented by Dancer et al. (1999). Those authors accommodate the change in basin polarity by transfer movements on a reactivated splay of the Great Glen Fault. Additional structural control may have been provided by an extension of the South Hatton Lineament which could define the northern margin of the Slyne High (SH) and then project south-eastwards across the basin in the area where the polarity change occurs.

\subsubsection{Porcupine Basin}

The modelled pre-Cenozoic sedimentary thickness has sharp inflections across the margins of the Porcupine Basin (PB) that are most probably related to fault zones. Comparison of the initial and optimised structure (Fig.3a and b respectively), particularly along the eastern margin of the basin, indicates that offsets between fault zones that compare well with structure identified by seismic surveys (e.g. Naylor et al., 2002). The western margin of the basin is more irregular in the model than in the structural element map of Naylor et al. (2002) with tongues of sediment extending further westward onto the Porcupine High than indicated by that map. One of these features, which lies just south of $52^{\circ} \mathrm{N}$, was identified by Readman et al. (2005), and related to a NW-trending fault system which they infer to have influenced basin evolution. The model reveals an asymmetry in the way the crystalline crust thins at the basin margins, with more rapid thinning on its western side (Fig. 5a), and this was also observed in wide-angle seismic data by O'Reilly et al. (2006).

Regardless of the nature of the basement beneath the Porcupine Basin, the free-air (Fig. 5a) and isostatic gravity anomaly high that coincides with the northern part of this basin indicates an isostatic imbalance. It is not possible to generate the positive gravity anomaly without placing the sedimentary infill at a higher level than would be dictated by local isostasy. Kimbell et al. (2004) illustrated how the gravity high can be explained by the influence of lithospheric strength during sediment loading, and estimated an effective elastic thickness of $10 \mathrm{~km}$ based on a sedimentary model extending approximately to base Cretaceous level. The subdivided sedimentary section provided by the current model provided an opportunity to test whether the strength is a largely Cenozoic phenomenon or extends back into the Mesozoic. 
When lithospheric strength was assumed to apply only during Cenozoic deposition, the predicted positive gravity anomaly over the Porcupine Basin was broader than that observed and offset to the north. The conclusion is that lithospheric strength did have an influence during Cretaceous times, and this is compatible with a sag phase following Late Jurassic earliest Cretaceous rifting (Naylor and Shannon, 2005). The implication is that any lithospheric weakening associated with partial serpentinisation of the mantle beneath the Porcupine Basin is offset by the strength of the underlying, unaltered and relatively strong lithospheric mantle, which is still thicker than the lithospheric mantle beneath the neighbouring highs.

\subsubsection{Basins to the south of Ireland}

The cover sequence thickness model (Fig. 4) emphasises the linear ENE-trending structural control over the North Celtic Sea Basin (NCSB), South Celtic Sea Basin (SCSB) and Western Approaches Basin (WAB). This contrasts with the NE- to NNE-trends which characterise the Fastnet Basin (FB) and, to the NE, the Kish Bank Basin (KBB), Central Irish Sea Basin (CISB), Peel Basin (PB) and Cardigan Bay Basin (CBB). The change in trend between the basins in the Celtic and Irish Seas could reflect the influence of Variscan structures in the former area, but there is a similar change in Caledonian features to the north of the Variscan Front including the Iapetus Suture, which swings from an ENE trend across the west of Ireland to a NE trend across the east of Ireland and back to an ENE trend beneath mainland Britain (Fig. 4; Phillips et al., 1976; McKerrow and Soper, 1989; Kimbell and Quirk, 1999; see also Readman et al., 1997). Kimbell and Stone (1995) and Kimbell and Quirk (1999) identified antecedents for these trends within the basement to the south of the Iapetus Suture beneath Britain. The ENE trend is followed, for example, by the Causey Pike Fault and Southern Borrowdales lineament of the Lake District (Cooper et al., 2004), and the more northerly trend is followed by the Welsh Borderland Fault System and other basement structures beneath northern England and the Irish Sea. Kimbell and Quirk (1999) concluded that the basement structures with these trends may have been initiated during the late Precambrian - early Cambrian assembly of Avalonia at the northern margin of Gondwana, and that they were subsequently subject to multiple phases of Caledonian reactivation, including rifting at the margins of the Iapetus Ocean and compressional deformation associated with the closure of that ocean (see also Hutton and Alsop, 1996). If the Avalonian basement to the south of Ireland has a similar structural fabric this could have influenced Caledonian and Variscan deformation in this region which, in turn, established the structural 
controls over subsequent basin evolution (cf. Bois et al., 1990; Ford et al., 1992; McCann and Shannon, 1994; McCann, 1996). The nature of the underlying continental basement may change in the extreme SE of the study area, because the northern margin of the Western Approaches Basin appears to lie along the extension of the Rheic Suture, which marks the boundary between Avalonian and Cadomian basement formed by the closure of the Rheic Ocean in late Silurian - early Devonian time (Pharaoh, 1999 and references therein).

\subsubsection{Continental margin in the south}

Apparent ENE- and NE-trending features in the model for the Goban Spur area are considered unreliable, probably arising from distortions in the observed gravity field relating to the merging of different data sources. Satellite-derived gravity data were employed in an area extending eastwards from the southern extremity of the Irish Designated Area (visible as a change in frequency content in Fig. 6a). A discrepancy between high-resolution bathymetry and low resolution gravity along the Western Appoaches - North Armorican margin results in further model distortion. Superior bathymetric sampling has led to the prediction of features which are not resolved by the gravity observations and thus accommodated by inaccurately modelled sediment thickness variations. For these reasons the modelling results in this area will not be discussed further.

\section{Magnetic modelling}

\subsection{Method}

Theoretical total magnetic field anomalies were calculated from the crustal structure defined by the gravity model, based on the assumption that the crystalline crust has a magnetisation of $1 \mathrm{~A} / \mathrm{m}$ in the direction of the Earth's present field (cf. Kimbell \& Stone 1995; Kimbell \& Quirk, 1997) and the volcanic layer in the Hatton-Edoras area has a reversed magnetisation of $3 \mathrm{~A} / \mathrm{m}$ (based on DSDP palaeomagnetic measurements). The result is displayed alongside the observed magnetic field in Fig. 8. The modelling does not attempt to simulate the effects of magnetic reversals within the oceanic crust but there is a broad zone of normally magnetised oceanic crust adjacent to the Porcupine - Goban Spur continental margin (crust formed during the Cretaceous normal polarity superchron, C34N), so it is instructive to include this in the comparison. The first reversed polarity interval (C33R) is well resolved in the observed magnetic field (Fig. 8a) and has been traced on the calculated field (Fig. 8b) for crossreference. 


\subsection{Results}

The magnetic modelling demonstrates that it is not possible to explain much of the observed shorter wavelength magnetic signal with the simple assumptions made. Substantial contributions are required from variations in basement magnetisation combined with a variety of intrusive and extrusive magnetic sources, including both reversely and normally magnetised units. The forward model does, however, reproduce some of the broader features of the magnetic field, showing that the regional magnetic lows over the Rockall and Porcupine basins can be explained by the thinning of magnetic crystalline crust beneath these basins. The magnetic crust probably extends westwards beneath the Hatton-Rockall area but the basement beneath the basins to the south and east of Ireland is less magnetic, as the sharp magnetic signatures over these basins in the forward magnetic model are not reflected by the observed field. This is probably because the upper part of the basement in this region comprises Lower Palaeozoic metasedimentary rocks which generally have lower magnetisation.

Within the southern part of the Hatton Basin, high amplitude NNE-trending linear magnetic highs and lows show a partial correlation with computed magnetic features associated with basement highs and lows resolved by the 3D modelling. However, differences in the detail of the anomaly pattern and the far smaller amplitudes of the anomalies in the forward magnetic model indicate that this is not simply a case of variations in the thickness of non-magnetic sediments over 'normal' magnetic crystalline basement. Strongly magnetic basement is present on the conjugate margin (calc-alkaline rocks within the Ketilidean orogen in southern Greenland) and may extend beneath the Hatton area, but the form of the anomalies does suggest the possibility of later igneous sources. For example, a pronounced linear positive magnetic anomaly extends almost $500 \mathrm{~km}$ in a NNE direction between $21^{\circ} \mathrm{W} 53^{\circ} \mathrm{N}$ and $18^{\circ} \mathrm{W}$ $57^{\circ} \mathrm{N}$ (MH in Fig. 8a) and is partially coincident with the Fangorn High (FH; Roberts, 1975; Roberts et al.,1979), and it is possible that the latter overlies a more extensive normally magnetised intrusive body (Edwards, 2002). Such bodies might be of Palaeogene and/or Cretaceous ages. If the latter, they could have been emplaced at the same time as the Barra Volcanic Ridge System (Bentley and Scrutton, 1987; Scrutton and Bentley, 1988).

The magnetic signatures change between the southern and northern parts of the Hatton Basin. In the north, the thickest parts of the cover sequence tend to correlate with magnetic highs rather than lows, possibly because reversely magnetised Palaeogene lavas are thinner beneath the basin than on its flanks, as a result of thickness changes across the lava escarpments 
observed at the basin margins. The NNE trend is less pronounced in the north, although there are weak indications of the continuity of magnetic lineaments across the divide. There are magnetic discontinuities at the South Hatton Lineament (Fig. 8a), and it appears possible that there may be an additional discontinuity slightly further north, in the vicinity of the median line. The latter is difficult to identify with confidence in the current compilation, however, because of a change in magnetic data quality across that line.

The observed magnetic field in the southern part of the Rockall Basin is dominated by the effects of the Barra Volcanic Ridge System, but further north there are subtle magnetic features in the observed field that appear to be due to variations in the depth and thickness of the crystalline crust beneath the basin (Fig. 8a). A significant proportion of these features are reproduced by the forward magnetic model (Fig.8b) suggesting that the optimisation process has recovered real variations in crustal structure.

\subsection{Insights from the pseudogravity transform in the Porcupine area}

Figure 9 illustrates the pseudogravity transform (Baranov, 1957) of the observed and calculated magnetic fields in the Porcupine area. This transform suppresses short-wavelength magnetic variations, helping to clarify similarities and differences between the longer wavelength components of these fields. The magnetic low associated with thinning of the crystalline crust beneath the Porcupine Basin is well resolved in both, but the version based on the observed field highlights lateral variations in basement magnetisation elsewhere in the area. A clear boundary, with more magnetic crust to the north, occurs just east of Ireland close to the offshore projection of the Iapetus Suture Zone (Fig.1). This configuration is comparable to that observed across Ireland and Britain and may be due to less magnetic metasedimentary rocks originally deposited on the margins of the Iapetus Ocean being juxtaposed against more magnetic crystalline basement to the north (Kimbell and Stone, 1995; Kimbell and Quirk, 1999). The magnetic boundary occurs close to the southern edge of the zone of north-dipping reflectors correlated with the Iapetus Suture Zone by Klemperer et al. (1991). Although the Variscan Front also trends towards this location it appears unlikely that it represents a sufficiently large structural disruption to be responsible for the observed magnetic effect (Ford et al., 1992). There is no evidence of a magnetisation boundary on the Porcupine High along the direct (WSW) projection of the feature identified just west of Ireland, so the most likely trajectory for the Iapetus Suture lies slightly further south, close to the southern end of this high. 
A further feature highlighted by the pseudogravity comparison is a zone of less magnetic crust to the north of the Porcupine Basin (PHB in Fig. 9a). This partially correlates with a local basin defined by the gravity model (PHB in Fig. 4) but the magnetic feature is more extensive. The most likely explanation is that there is a belt of sedimentary/metasedimentary (Palaeozoic?) rocks that has low magnetisation but only locally a low density. The southern boundary of this feature lies along the projection of the Skerd Rocks (Southern Upland) Fault (Fig. 4).

There is a distinct contrast between the observed pseudogravity anomalies over the oceanic basement adjacent to the Porcupine-Goban Spur margin and those over the eastern side of the Rockall Basin (Fig. 9a). This suggests that the former has a higher magnetisation than the latter, as their modelled (and seismically defined) thicknesses and theoretical psuedogravity responses (Fig. 9b) are similar. The observed difference in magnetisation is explicable if it is assumed that there is normally magnetised igneous oceanic crust in the south while the Rockall Basin is underlain by highly stretched and less magnetic continental crust. This interpretation differs from the hypotheses that the Rockall Basin is floored by oceanic crust of mid-Cretaceous age (e.g. Chappell and Kusznir, 2005) or that the Porcupine Abyssal Plain adjacent to Goban Spur margin is underlain by exhumed, serpentinised mantle (Bullock and Minshull, 2005). Measurements of the magnetisation of serpentinised peridotite from exhumed mantle on the Iberian margin indicate values that are significantly less than those for oceanic basalts (Zhao, 1996; Zhao et al., 2001; Russell and Whitmarsh, 2003). Sibuet et al. (2007) argued that some magnetic anomalies in this area could relate to serpentinisation, but conceded that the magnetisations involved are lower and more variable than those characteristic of igneous ocean crust. On the North Armorican margin the ocean-continent transition zone identified by Thinon et al. (2003), which may contain exhumed mantle, has a much more subdued magnetic signature than the normal oceanic crust to the south.

Our preferred interpretation is that that the extensive zone of magnetic basement adjacent to the Porcupine-Goban margin is mainly composed of igneous oceanic crust formed during the Cretaceous normal-polarity superchron $(\mathrm{C} 34 \mathrm{~N})$. If exhumed mantle occurs within this area we suggest that it may have only limited extent. Such a hypothesis receives some support from the presence of a relative magnetic low which appears to coincide with the anomalous basement identified by Bullock and Minshull (2005) near the western end of the WAM profile (compare their figs. 2a and 9), but further investigation would be necessary to confirm this. 


\section{Concluding remarks}

The new modelling results are similar to those for the Irish part of the NE Atlantic margin in the 3D model of Kimbell et al. (2004, 2005), but with a marked improvement in the resolution of cover sequence structure. The key factors leading to this improvement were a more accurate representation of the initial geometry of this sequence and the density variations within it, and higher resolution sampling of the observed gravity field available from marine survey data acquired for the Irish National Seabed Survey. The results obtained over better-known structures, such as the Slyne and Erris basins, indicate that gravity inversion has resolved structure that can be validated by comparison with seismic evidence. This gives confidence in the delineation of less well-known structures such as the Ciarán and Colmán basins and further, previously unidentified basins on the Rockall High. Further apparent Mesozoic rifts beneath the Hatton Basin and Hatton-Edoras High are more speculative, because of uncertainties in modelling the overlying sequence and the possible influence of igneous units, but nonetheless represent suitable targets for further investigation.

The modelled configuration of the main deep water basins conforms to that identified by a number of previous studies, with highly stretched crust beneath the Rockall and Porcupine basins and a lower degree of stretching beneath the Hatton Basin. Forward modelling indicates that the broad magnetic anomaly pattern across the Rockall and Porcupine basins can be explained in terms of variations in the thickness of the magnetic crystalline crust. Superimposed on this are anomalies associated with intra-basement magnetisation variations, for example between magnetic crystalline rocks in the hanging wall of the Iapetus Suture and non-magnetic metasedimentary rocks in its footwall. The magnetic expression of the Hatton Basin appears to have been strongly influenced by igneous rocks of Palaeogene and possibly also Cretaceous ages.

Magnetic signatures across the eastern margin of the Rockall Basin and the continent-ocean boundary in the adjacent Porcupine - Goban Spur area suggests that the former area is floored by highly stretched continental crust, perhaps including areas of exhumed upper mantle, and the latter by igneous ocean crust. If the main extensional event in the basin was earliest Cretaceous in age then this amagmatic response to stretching would be compatible with that which occurred on the Iberian margin at that time (Pinheiro et al., 1996). A strongly contrasting magnetic expression is associated with the Barra Volcanic ridges in the southernmost part of the Rockall Basin. The age of these is not known, but their cross-basin (NW) trend suggests that they could be an igneous manifestation of a later stretching event 
that occurred under conditions more conducive to magmatic activity. The presence of volcanic rocks on the Labrador margin (Alexis Formation) lying immediately beneath sandstones of Albian age (Balkwill, 1987), and of igneous ocean crust of similar age off the Goban Spur margin (at least in our interpretation), suggests that such conditions had been established by mid-Cretaceous times. Magmatism of this age might also explain some of the magnetic responses observed in the Hatton Basin area. The gravity response over the area spanned by the Barra Volcanic Ridges suggests relatively strong and perhaps incipient oceanic lithosphere beneath this area. Final breakup did not, however, proceed along this axis but transferred westward along the Charlie Gibbs transform.

\section{Acknowledgements}

The modelling project that provided the basis for this paper was sponsored by the Irish Shelf Petroleum Studies Group (ISPSG; part of Ireland's Petroleum Infrastructure Programme). We thank the ISPSG Secretariat and Petroleum Affairs Division (Department of Communications, Energy and Natural Resources) for their assistance with initiating the project and the Geological Survey of Ireland for kindly providing data from the Irish National Seabed Survey. This paper is published with the permission of the Executive Director of the British Geological Survey (NERC). 


\section{References}

Allen, P.A., Bennett, S.D., Cunningham, M.J.M., Carter, A., Gallagher, K., Lazzaretti, E., Galewsky, J., Densmore, A.L., Phillips, W.E.A., Naylor, D., Solla Hach, C., 2002. The post-Variscan thermal and denudational history of Ireland. In: Doré, A G, Cartwright, J A, Stoker, M S, Turner, J P, and White, N J (Eds.), Exhumation of the North Atlantic margin: Timing, Mechanisms and Implications for Petroleum Exploration. Special Publication of the Geological Society, London 196, 371-399.

Balkwill, H.R., 1987. Labrador Basin: structural and stratigraphic style. Memoir of the Canadian Society of Petroleum Geologists 12, 17-43.

Baranov, V., 1957. A new method for the interpretation of aeromagnetic maps: pseudogravimetric anomalies. Geophysics 22 359-383.

Barton, A.J., White R.S., 1997a. Crustal structure of Edoras Bank continental margin and mantle thermal anomalies beneath the North Atlantic. Journal of Geophysical Research 102, B2, 3109-3129.

Barton, A.J., White, R.S., 1997b. Volcanism on the Rockall continental margin. Journal of the Geological Society, London 154, 531-536.

Bassi, G., 1995. Relative importance of strain rate and rheology for the mode of continental extension. Geophysical Journal International 122, 195-210.

Bentley, P.A.D., Scrutton, R.A., 1987. Seismic investigations into the basement structure of southern Rockall Trough. In: Brooks, J. and Glennie, K.W. (Eds.), Petroleum Geology of Northwest Europe: Proceedings of the 3rd Conference. Graham and Trotman, London, pp. 667-675.

BIRPS and ECORS, 1986. Deep seismic reflection profiling between England, France and Ireland. Journal of the Geological Society, London 143, 45-52.

Bois, C., Lefort, J.-P., Le Gall, B., Sibuet, J.-C., Gariel, O., Pinet, B., Cazes, M., 1990. Superimposed Variscan, Caledonian and Proterozoic features inferred from deep seismic profiles recorded between southern Ireland, southwestern Britain and western France. Tectonophysics 177, 15-37.

Boldreel, L.O., Andersen, M.S., 1994. Tertiary development of the Faroe-Rockall Plateau based on seismic reflection data. Bulletin of the Geological Society of Denmark 41, 169-180.

Bonneville, A., Capolsini, P., 1999. THERMIC: a tool to solve conductive and advective heat transfer problems in Earth sciences. Computer and Geosciences 25, 1137-1148.

Bott, M.H.P., Watts, A.B., 1971. Deep structure of the continental margin adjacent to the British Isles. In: Delaney, F.M. (Ed.), The geology of the East Atlantic continental margin. 2. Europe. Report of the Institute of Geological Sciences 70/14, 89-109.

Breivik, A.J., Verhoef, J., Faleide, J.I., 1999. Effect of thermal contrasts on gravity modelling at passive margins: results from the western Barents Sea. Journal of Geophysical Research 104, 15293-15311.

Bullock, A.D., Minshull, T.A., 2005. From continental extension to seafloor spreading: crustal structure of the Goban Spur rifted margin, southwest of the UK. Geophysical Journal International 163, 527-546.

Chadwick, R.A., Jackson, D.I., Barnes, R.P., Kimbell, G.S., Johnson, H., Chiverrell, R.C., Thomas, G.S.P., Jones, N.S., Riley, N.J., Pickett, E.A., Young, B., Holliday, D.W., Ball, D.F., Molyneux, S.G., Long, D., Power, G.M., Roberts, D.H., 2001. Geology of the Isle of Man and its offshore area. British Geological Survey Research Report, RR/01/06.

Chapman, M.E., Bodine, J., 1979. Considerations of the indirect effect in marine gravity modelling. Journal of Geophysical Research 84, 3889-3892.

Chapman, T.J., Broks, T.M., Corcoran, D.V., Duncan, L.A., Dancer, P.N., 1999. The structural evolution of the Erris Trough, offshore northwest Ireland, and implications for hydrocarbon generation. In: Fleet, A.J., Boldy, S A.R. (Eds.), Petroleum Geology of Northwest Europe: Proceedings of the 5th Conference. The Geological Society, London, pp. 455-469.

Chappell, A.R., Kusznir, N.J., 2005. Crustal thickness mapping using satellite gravity data: implications for the formation of the southern Rockall Trough. Geophysical Research Abstracts 7, 07953.

Conroy, J.J., Brock, A., 1989. Gravity and magnetic studies of crustal structure across the Porcupine basin west of Ireland. Earth and Planetary Science Letters 93, 371-376. 
Cooper, A.H., Fortey, N.J., Hughes, R.A., Molyneux, S.G., Moore, R.M., Rushton, A.W.A., Stone, P., 2004. The Skiddaw Group of the English Lake District. Memoir of the British Geological Survey.

Corfield, S., Murphy, N., Parker, S., 1999. The structural and stratigraphic framework of the Irish Rockall Trough. In: Fleet, A.J., Boldy, S.A.R. (Eds.), Petroleum Geology of Northwest Europe: Proceedings of the 5th Conference. The Geological Society, London, pp. 407-420.

Croker, P.F., 1995. The Clare Basin; a geological and geophysical outline. In: Croker, P.F., Shannon, P.M. (Eds.), The Petroleum Geology of Ireland's Offshore Basins. Special Publication of the Geological Society, London 93, 327-339.

Croker, P.F., Shannon, P.M., 1987. The evolution and hydrocarbon prospectivity of the Porcupine Basin, Offshore Ireland. In: Brooks, J. and Glennie, K.W. (eds) Petroleum Geology of NW Europe, Proceedings of the 3rd Conference. Graham and Trotman, London, pp. 633-642.

Dabek, Z.K., Williamson, J.P., 1999. Forward and inverse wavenumber formulae for the gravity and magnetic responses of layered models. British Geological Survey Technical Report WK/99/03C.

Dancer, P.N., Algar, S.T., Wilson, I.R., 1999. Structural evolution of the Slyne Trough. In: Fleet, A.J., Boldy, S.A.R. (Eds.), Petroleum Geology of Northwest Europe: Proceedings of the 5th Conference. The Geological Society, London, pp. 445-453.

Dancer, P.N., Kenyon-Roberts, S.M., Downey, J.W., Baillie, J.M., Meadows, N.S., .Maguire, K., 2005. The Corrib gas field, offshore west of Ireland. In: Doré, A.G., Vining, B.A. (Eds), Petroleum Geology: North-West Europe and Global Perspectives - Proceedings of the 6th Petroleum Geology conference. The Geological Society, London, pp. 1035-1046.

De Graciansky, P.C., Poag, C.W. et al., 1985. Initial Reports of the Deep Sea Drilling Program, Leg 80.

DeSilva, N.R., 1999. Sedimentary basins and petroleum systems offshore Newfoundland and Labrador. In: Fleet, A.J., Boldy, S.A.R. (Eds.), Petroleum Geology of Northwest Europe: Proceedings of the 5th Conference. The Geological Society, London, pp. 501-515.

Doré, A.G., Cartwright, J.A., Stoker, M.S., Turner, J.P., White, N. (Eds.), 2002a. Exhumation of the North Atlantic margin: Timing, Mechanisms and Implications for Petroleum Exploration. Special Publication of the Geological Society, London 196.

Doré, A.G., Corcoran, D.V., Scotchman, I.C., 2002b. Prediction of the hydrocarbon system in exhumed basins, and application to the NW European margin. In: Doré, A G, Cartwright, J A, Stoker, M S, Turner, J P, and White, N J (Eds.), Exhumation of the North Atlantic margin: Timing, Mechanisms and Implications for Petroleum Exploration. Special Publication of the Geological Society, London 196, 401-429.

Dunford, G.M., Dancer, P.N., Long, K.D., 2001. Hydrocarbon potential of the Kish Bank Basin: integration within a regional model for the greater Irish Sea Basin. In: Shannon, P.M., Haughton, P.D.W., Corcoran, D.V. (Eds.), The Petroleum Exploration of Ireland's Offshore Basins. Special Publication of the Geological Society, London 188, 135-154.

Edwards, J.W.F., 2002., Development of the Hatton-Rockall Basin, north-east Atlantic Ocean. Marine and Petroleum Geology 19, 193-205.

Ellis, D., Bell, B.R., Jolley, D.W., O’Callaghan, M., 2002. The stratigraphy, environment of eruption and age of the Faroes Lava Group, NE Atlantic Ocean. In: Jolley, D.W., Bell, B.R. (Eds.), The North Atlantic Igneous Province: Stratigraphy, Tectonic, Volcanic and Magmatic Processes. Special Publication of the Geological Society, London 197, 253-269.

England, R.W., Hobbs, R.W., 1997. The structure of the Rockall Trough imaged by deep seismic reflection profiling. Journal of the Geological Society, London 154, 497-502.

Evans, C.D.R., Hillis, R.R., Gatliff, R.W., Day, G.A., Edwards, J.W.F., 1990. United Kingdom offshore regional report: the geology of the western English Channel and its western approaches. HMSO for the British Geological Survey, London.

Floodpage, J., Newman, P., White, J., 2001. Hydrocarbon prospectivity in the Irish Sea area: insights from recent exploration of the Central Irish Sea, Peel and Solway basins. In: Shannon, P.M., Haughton, P.D.W., Corcoran, D.V. (Eds.), The Petroleum Exploration of Ireland's Offshore Basins. Special Publication of the Geological Society, London 188, 107-134. 
Ford, M., Klemperer, S.L., Ryan, P.D., 1992. Deep structure of southern Ireland: a new geological synthesis using BIRPS deep reflection profiling. Journal of the Geological Society, London 149, 915-922.

Fyfe, J.A., Long, D., Evans, D., Abraham, D.A., 1993. United Kingdom offshore regional report: the geology of the Malin-Hebrides Sea area. HMSO for the British Geological Survey, London.

Hanisch, J., 1984. The Cretaceous opening of the northeast Atlantic. Tectonophysics 101, 1-23.

Haszeldine, R.S., Russell, M.J., 1987. The Late Carboniferous northern North Atlantic Ocean: implications for hydrocarbon exploration from Britain to the Arctic. In: Brooks, J, Glennie, K.W. (Eds.) Petroleum Geology of NW Europe, Proceedings of the 3rd Conference. Graham and Trotman, London, pp. 1163-1175.

Haughton, P., Praeg, D., Shannon, P., Harrington, G., Higgs, K., Amy, L., Tyrrell, S., Morrissey, T., 2005. First results from shallow stratigraphic boreholes on the eastern flank of the Rockall Basin, offshore western Ireland. In: Doré, A.G., Vining, B.A. (Eds), Petroleum Geology: North-West Europe and Global Perspectives Proceedings of the 6th Petroleum Geology conference. The Geological Society, London, pp.1077-1094.

Hauser, F., O’Reilly, B.M., Jacob, A.W.B., Shannon, P.M., Makris, J., Vogt, U., 1995. The crustal structure of the Rockall Trough: differential stretching without underplating. Journal of Geophysical Research 100, 40974116.

Hillis, R., 1995. Regional Tertiary exhumation in and around the United Kingdom. In: Buchanan, J.G., Buchanan, P.G. (Eds.), Basin Inversion. Special Publication of the Geological Society, London 88, 167-190.

Hitchen, K., 2004. The geology of the UK Hatton-Rockall margin. Marine and Petroleum Geology 21, 9931012.

Hutton, D.H.W., Alsop, G.I., 1996. The Caledonian strike-swing and associated lineaments in NW Ireland and adjacent areas: sedimentation, deformation and igneous intrusion patterns. Journal of the Geological Society, London 153, 345-360.

Izatt, C., Maingarm, S., Racey, A., 2001. Fault distribution and timing in the Central Irish Sea Basin. In: Shannon, P.M., Haughton, P.D.W., Corcoran, D.V. (Eds.), The Petroleum Exploration of Ireland's Offshore Basins. Special Publication of the Geological Society, London 188, 155-169.

Johnson, H, Ritchie, J.D., Gatliff, R.W., Williamson, J.P., Cavill, J., Bulat, J., 2001. Aspects of the structure of the Porcupine and Porcupine Seabight basins as revealed from gravity modelling of regional seismic transects. In: Shannon, P.M., Haughton, P.D.W., Corcoran, D.V. (Eds.), The Petroleum Exploration of Ireland's Offshore Basins. Special Publication of the Geological Society, London 188, 265-274.

Joppen, M., White, R.S., 1990. The structure and subsidence of Rockall Trough from two-ship seismic experiments. Journal of Geophysical Research 95 (B12), 19821-19837.

Keser Neish, J., 1993. Seismic structure of the Hatton-Rockall area: an integrated seismic/modelling study from composite datasets. In: Parker, J.R. (Ed.), Petroleum Geology of Northwest Europe: Proceedings of the 4th Conference. The Geological Society, London, pp. 1047-1056.

Kimbell, G.S., Stone, P., 1995. Crustal magnetisation variations across the Iapetus Suture Zone. Geological Magazine 132, 599-609.

Kimbell, G.S., Quirk, D.G., 1999. Crustal magnetic structure of the Irish Sea region: evidence for a major basement boundary beneath the Isle of Man. In: Woodcock, N.H., Quirk, D.G., Fitches, W.R., Barnes, R.P. (Eds.), In sight of the suture: the geology of the Isle of Man in its Iapetus Ocean context. Special Publication of the Geological Society, London 160, 227-238.

Kimbell, G.S., Gatliff, R.W., Ritchie, J.D., Walker, A.S.D., Williamson, J.P., 2004. Regional three-dimensional modelling of the NE Atlantic margin. Basin Research 16, 259-278.

Kimbell, G.S., Ritchie, J.D., Johnson, H., Gatliff, R.W., 2005. Controls on the structure and evolution of the NE Atlantic margin revealed by regional potential field imaging and 3D modelling. In: Doré, A.G., Vining, B.A. (Eds), Petroleum Geology: North-West Europe and Global Perspectives - Proceedings of the 6th Petroleum Geology conference. The Geological Society, London, pp. 933-945.

Klemperer, S.L., Ryan, P.D., Snyder, D.B., 1991. A deep seismic reflection profile across the Irish Caledonides. Journal of the Geological Society, London 148, 149-164.

Klingelhöfer, F., Edwards, R.A., Hobbs, R.W. and England, R.W., 2005. Crustal structure of the NE Rockall Trough from wide-angle seismic data modelling. Journal of Geophysical Research, 110, B11105, 1-25. 
Knott, S.D., Burchell, M.T., Jolley, E.J. and Fraser, A.J., 1993. Mesozoic to Cenozoic plate reconstructions of the North Atlantic and hydrocarbon plays of the Atlantic margins. In: Parker, J.R. (Ed.), Petroleum Geology of Northwest Europe: Proceedings of the 4th Conference. The Geological Society, London, pp. 953-974.

Kristofferson, Y., 1978. Sea-floor spreading and the early opening of the North Atlantic. Earth and Planetary Science Letters 38, 273-290.

Louden, K.E., Tucholke, B.E., Oakey, G.N., 2004. Regional anomalies of sediment thickness, basement depth and isostatic crustal thickness in the North Atlantic Ocean. Earth and Planetary Science Letters 224, 193-211.

Louvel, V., Dyment, J., Sibuet, J.-C., 1997. Thinning of the Goban Spur continental margin and formation of early ocean crust: constraints from forward modelling and inversion of marine magnetic anomalies. Geophysical Journal International 128, 188-196.

McCann, T., 1996. The North Celtic Sea reflector - a possible basement structure, offshore southern Ireland. Tectonophysics 266, 361-377.

McCann, T., Shannon, P.M., 1994. Late Mesozoic reactivation of Variscan faults in the North Celtic Sea Basin, Ireland. Marine and Petroleum Geology 11, 94-103.

Mackenzie, G.D., Shannon, P.M., Jacob, A.W.B., Morewood, N.C., Makris, J., Gaye, M., Egloff, F., 2002. The velocity structure of the sediments in the southern Rockall Basin: results from new wide-angle seismic modelling. Marine and Petroleum Geology 19, 983-1003.

McKerrow, W.S., Soper, N.J., 1989. The Iapetus suture in the British Isles. Geological Magazine 126, 1-8.

Masson, D.G., Montadert, L., Scrutton R.A., 1985. Regional geology of the Goban Spur continental margin. Initial Reports of the Deep Sea Drilling Project 80, 1115-1139.

Megson, J.B., 1987. The evolution of the Rockall Trough and implications for the Faroe-Shetland Tough. In: Brooks, J. and Glennie, K.W. (eds) Petroleum Geology of NW Europe, Proceedings of the 3rd Conference. Graham and Trotman, London, 653-665.

Morewood, N.C., Mackenzie, G.D., Shannon, P.M., O’Reilly, B.M., Readman, P.W., Makris, J., 2005. The crustal structure and regional development of the Irish Atlantic margin region. In: Doré, A.G., Vining, B.A. (Eds), Petroleum Geology: North-West Europe and Global Perspectives - Proceedings of the 6th Petroleum Geology conference. The Geological Society, London, pp. 1023-1033.

Müller, R.D., Roest W.R., Royer, J.-Y., Gahagan, L.M., Sclater, J.G., 1997. Digital isochrons of the world's ocean floor. Journal of Geophysical Research 102, 3211-3214.

Murdoch, L.M., Musgrove, F.W., Perry, J.S., 1995. Tertiary uplift and inversion history in the North Celtic Sea Basin and its influence on source rock maturity. In: Crocker, P.F., Shannon, P.M. (Eds.), The Petroleum Geology of Ireland's Offshore Basins. Special Publication of the Geological Society, London 93, 297-319.

Musgrove, F.W., Mitchener, B., 1996. Analysis of the pre-Tertiary history of the Rockall Trough. Petroleum Geoscience 2, 353-360.

Nadin, P.A., Houchen, M.A., Kuznir, N.J., 1999. Evidence for pre-Cretaceous rifting in the Rockall Trough: an analysis using quantitative 2D structural/stratigraphic modelling. In: Fleet, A.J. and Boldy, S.A.R. (eds) Petroleum Geology of Northwest Europe: Proceedings of the 5th Conference. The Geological Society, London, 371-378.

Naylor, D., Shannon P.W., 2005. The structural framework of the Irish Atlantic Margin. In: Doré, A.G., and Vining, B. (Eds.) Petroleum Geology: North-West Europe and Global Perspectives - Proceedings of the 6th Petroleum Geology Conference. The Geological Society, London, pp. 1009-1022.

Naylor, D., Shannon, P., Murphy, N., 1999. Irish Rockall Basin region - a standard structural nomenclature system. Petroleum Affairs Division, Special Publication 1/99.

Naylor, D., Shannon, P., Murphy, N., 2002. Porcupine-Goban region - a standard structural nomenclature system. Petroleum Affairs Division, Special Publication 1/02.

Oldenburg, D.W., 1974., The inversion and interpretation of gravity anomalies. Geophysics 39, 526-536.

O'Reilly, B.M., Hauser, F., Jacob, A.W.B., Shannon, P.M., Makris, J., Vogt, U., 1995. The transition between the Erris and the Rockall Basins: new evidence from wide-angle seismic data. Tectonophysics 241, 143-163.

O'Reilly, B.M., Hauser, F., Jacob, A.W.B., Shannon, P.M., 1996. The lithosphere below the Rockall Trough: wide-angle seismic evidence for extensive serpentinisation. Tectonophysics 255, 1-23. 
O’Reilly, B.M, Readman, P.W., Hauser, F., 1998. Lithospheric structure across the western Eurasian plate from a wide-angle seismic and gravity study: evidence for a regional thermal anomaly. Earth and Planetary Science Letters 156, 275-280.

O’Reilly B.M., Hauser, F., Ravaut, C., Shannon, P.M., Readman, P.W., 2006. Crustal thinning, mantle exhumation and serpentinization in the Porcupine Basin. Journal of the Geological Society, London 163, 775787.

Parker, R.L., 1972. The rapid calculation of potential anomalies. Geophysical Journal of the Royal Astronomical Society 31, 447-455.

Pérez-Gussinyé, M., Reston, T.J., Phipps Morgan, J., 2001. Serpentinization and magmatism during extension at non-volcanic margins: the effect of initial lithospheric structure. In: Wilson, R.C.L., Whitmarsh, R.B., Taylor, B., Froitzheim, N. (Eds.), Non-volcanic rifting of continental margins: a comparison of evidence from land and sea. Special Publication of the Geological Society, London 187, 551-576.

Pharaoh, T.C., 1999. Palaeozoic terranes and their lithospheric boundaries within the Trans-European Suture Zones (TESZ): a review. Tectonophysics 314, 17-41.

Phillips, W.E.A., Stillman, C.J., Murphy, T., 1976. A Caledonian plate tectonic model. Journal of the Geological Society, London 132, 579-609.

Pinheiro, L.M., Wilson, R.C.L., Reis, P.D., Whitmarsh, R.W., Ribeiro, A., 1996. The Western Iberian margin: a geophysical and geological overview. In: Whitmarsh, R.B., Sawyer, D.S., Klaus, A., Masson, D.G. (Eds.), Proceedings of the Ocean Drilling Program, Scientific Results, 149, 3-23.

Readman, P.W., O’Reilly, B.M., Murphy, T. 1997. Gravity gradients and upper crustal tectonic fabrics, Ireland. Journal of the Geological Society, London 154, 817-828.

Readman, P.W., O’Reilly, B.M., Shannon, P.M., Naylor, D., 2005. The deep structure of the Porcupine Basin, offshore Ireland, from gravity and magnetic studies. In: Doré, A.G., Vining, B.A. (Eds), Petroleum Geology: North-West Europe and Global Perspectives - Proceedings of the 6th Petroleum Geology conference. The Geological Society, London, pp. 1047-1056.

Reston, T.J., 2009. The structure, evolution and symmetry of the magma-poor rifted margins of the North and Central Atlantic. Tectonophysics 468, 6-27.

Reston, T.J., Pennell, J., Stubenrauch, A., Walker, I., Perez-Gussinye, M., 2001. Detachment faulting, mantle serpentinization and serpentinite mud volcanism beneath the Porcupine Basin SW of Ireland. Geology 29, 587590.

Reston, T.J., Gaw, V., Pennell, J., Klaeschen, D., Stubenrauch, A., Walker, I., 2004. Extreme crustal thinning in the south Porcupine Basin and the nature of the Porcupine Median High: implications for the formation of nonvolcanic rifted margins. Journal of the Geological Society, London 161, 783-798.

Roberts, D.G., 1975. Marine geology of the Rockall Plateau and Trough. Philosophical Transactions of the Royal Society of London, Series A 278, 447-509.

Roberts, D.G., Montadert, L., Searle, R C., 1979. The western Rockall plateau: stratigraphy and structural evolution. Initial Reports of the Deep Sea Drilling Programme 48, 1061-1088.

Roberts, D.G., Ginzberg, A., Nunn, K., McQuillin, R., 1988. The structure of the Rockall Trough from seismic refraction and wide-angle reflection measurements. Nature 332, 632-635.

Roberts, D.G., Thompson, M., Mitchener, B., Hossack, J., Carmichael, S. and Bjornseth, H-M., 1999. Palaeozoic to Tertiary rift and basin dynamics: mid-Norway to the Bay of Biscay - a new context for hydrocarbon prospectivity in the deep water frontier. In: Fleet, A.J. and Boldy, S.A.R. (eds) Petroleum Geology of Northwest Europe: Proceedings of the 5th Conference. The Geological Society, London, pp. 7-40.

Russell, M.J., Smythe, D.K., 1978. Evidence for an Early Permian oceanic rift in the northern North Atlantic. In: Neumann, E.-R. and Ramberg, I.B. (Eds.), Petrology and geochemistry of continental rifts. Riedel, Dordrecht, pp. 173-179.

Russell, S.M., Whitmarsh, R.B., 2003. Magmatism at the west Iberia non-volcanic rifted continental margin: evidence from analyses of magnetic anomalies. Geophysical Journal International 154, 706-730.

Sandwell, D.T., Smith, W.H.F., 1997. Marine gravity anomaly from Geosat and ERS 1 satellite altimetry. Journal of Geophysical Research 102, 10039-10054. 
Sclater, J.G., Christie, P.A.F., 1980. Continental stretching: an explanation of the post-mid-Cretaceous subsidence of the central North Sea basin. Journal of Geophysical Research 85, 3711-3739.

Scrutton, R.A.., 1985. Modelling of magnetic and gravity anomalies at Goban Spur, northeast Atlantic. Initial Reports of the Deep Sea Drilling Program 80, 1141-1151.

Scrutton, R.A., Bentley, P.A.D., 1988. Major Cretaceous volcanic province in the southern Rockall Trough. Earth and Planetary Science Letters 91, 198-204

Shannon P.M., Jacob, A.W.B., Makris, J., O'Reilly, B., Hauser, F., Vogt, U., 1994. Basin evolution in the Rockall region, North Atlantic. First Break 12, 515-522.

Shannon, P.M., Jacob, A.W.B., O’Reilly, B.M., Hauser, F., Readman, P.W., Makris, J., 1999. Structural setting, geological development and basin modelling in the Rockall Trough. In: Fleet, A.J., Boldy, S.A.R. (Eds.), Petroleum Geology of Northwest Europe: Proceedings of the 5th Conference. The Geological Society, London, pp. 421-431.

Shannon, P.M., Corcoran, D.V., Haughton, P.D.W., 2001. The petroleum geology of Ireland's offshore basins: introduction. In: Shannon, P.M., Haughton, P.D.W., Corcoran, D.V. (Eds.), The Petroleum Exploration of Ireland's Offshore Basins. Special Publication of the Geological Society, London 188, 1-8.

Sibuet, J.-C., Srivastava, S., Manatschal, G., 2007. Exhumed mantle-forming transitional crust in the Newfoundland-Iberia rift and associated magnetic anomalies. Journal of Geophysical Research 112 (B6), B06105, doi:10.1029/2005JB003856.

Smith, L.K., White, R.S., Kusznir, N.J., the iSIMM Team, 2005. Structure of the Hatton Basin and adjacent continental margin. In: Doré, A.G., Vining, B.A. (Eds), Petroleum Geology: North-West Europe and Global Perspectives - Proceedings of the 6th Petroleum Geology Conference. The Geological Society, London, pp. 947956.

Smith, L.K., 2006. Crustal structure of Hatton Bank volcanic continental margin from traveltime inversion of wide-angle data. Unpublished PhD Thesis, University of Cambridge.

Smythe, D.K., 1989. Rockall Trough - Cretaceous or Late Palaeozoic? Scottish Journal of Geology 25, 5-43.

Srivastava, S.P., Voppel, D., Tucholke, B., 1988. Geophysical Atlas of the North Atlantic $50^{\circ}$ to $72^{\circ} \mathrm{N}$ and $0^{\circ}$ to $65^{\circ} \mathrm{W}$. Deutsches Hydrographisches Institut, Hamburg.

Tate, M.P., Dobson, M.R., 1988. Syn- and post-rift igneous activity in the Porcupine Seabight Basin and adjacent continental margin W of Ireland. In: Morton, A.C., Parson, L.M. (Eds.), Early Tertiary Volcanism and the Opening of the NE Atlantic. Special Publication of the Geological Society, London 39, 309-334.

Thinon, I., Matias, L., Réhault, J.P., Hirn, A., Fidalgo-González, L., Avedik, F., 2003. Deep structure of the Armorican Basin (Bay of Biscay): a review of Norgasis seismic reflection and refraction data. Journal of the Geological Society, London 160, 99-116.

Tucker, R.M., Arter, G., 1987. The tectonic evolution of the North Celtic Sea and Cardigan Bay basins with special reference to basin inversion. Tectonophysics 137, 291-307.

Verhoef, J., Roest, W.R., MacNab, R., Arkani-Hamed, J., et al., 1996. Magnetic anomalies of the Arctic and North Atlantic Oceans and adjacent land areas. Geological Survey of Canada Open File Report, No. 3125a.

Vogt, U., Makris, J., O’Reilly, B.M., Hauser, F., Readman, P.W., Jacob, A.W.B., Shannon, P.M., 1998. The Hatton Basin and continental margin: crustal structure from wide-angle seismic and gravity data. Journal of Geophysical Research 103, 12545-12566.

White, R.S., 1992. Crustal structure and magmatism of North Atlantic continental margins. Journal of the Geological Society, London 149, 841-854.

White, R.S., McKenzie, D., 1989. Magmatism at rift zones: The generation of volcanic continental margins and flood basalts. Journal of Geophysical Research 94, 7685-7729.

Zhao, X., 1996. Magnetic signatures of peridotite rocks from Sites 897 and 899 and their implications. In: Whitmarsh, R.B., Sawyer, D.S., Klaus, A., Masson, D.G. (Eds.), Proceedings of the Ocean Drilling Program, Scientific Results 149, 431-446.

Zhao, X., Turrin, B.D., Jackson, M., Solheid, P., 2001. Data report: Paleomagnetic and rock magnetic characterization of rocks recovered from Leg 173 sites. In: Beslier, M.-O., Whitmarsh, R.B., Wallace, P.J., Girardeau, J. (Eds.), Proceedings of the Ocean Drilling Program, Scientific Results 173, 1-34 [Online]. 


\section{Figure captions}

Fig. 1 Structural elements of the Irish continental shelf, mainly based on Naylor et al. (1999, 2002). Age of ocean crust (in Ma) after Müller et al. (1997). Abbreviations: BVRS = Barra Volcanic Ridge System; CAB = Canice Basin; $\mathrm{CBB}=$ Cardigan Bay Basin; CIAB = Ciarán Basin; $\mathrm{CB}=$ Cillian Basin; CISB $=$ Central Irish Sea Basin; $\mathrm{CMB}=$ Colm Basin; $\mathrm{CNB}=$ Connall Basin; $\mathrm{COB}=$ Cockburn Basin; $\mathrm{COLB}=$ Colmán Basin; $\mathrm{EB}=$ Erris Basin; EH = Erris High; FB = Fastnet Basin; FH = Fangorn High; FHCB = Fair Head - Clew Bay line; GGF $=$ Great Glen Fault; HRB = Hatton Ridge basins; IS = Iapetus Suture; KBB = Kish Bank Basin; $\mathrm{MB}=$ Malin Basin; $\mathrm{MDB}=$ Macdara Basin; $\mathrm{NBB}=$ North Bróna Basin; $\mathrm{OHH}=$ Outer Hebrides High; PEB = Peel Basin; PVRS = Porcupine Volcanic Ridge System; ROB = Rónán Basin (/ Ladra High); SB = Slyne Basin; SBB = South Bróna Basin; SH = Slyne High; $\mathrm{STH}=$ Stanton High; SUF $=$ Southern Upland Fault; VF = Variscan Front.

Fig. 2 Components of the initial cover sequence model. (a) Topography; (b) thickness of Cenozoic sedimentary rocks; (c) assumed thickness of Palaeogene volcanic rocks in the Rockall-Hatton area; and (d) assumed denudation affecting the pre-Cenozoic sequence. Where volcanic rocks are present, map $\mathrm{b}$ represents the post-volcanic succession.

Fig. 3 Thickness of pre-Cenozoic (/pre-volcanic) sedimentary rocks (a) before and (b) after model optimisation.

Fig. 4 Total cover sequence thickness in the optimised model. R33 = RAPIDS 33 profile (see Fig. 7). Annotations as in Fig. 1, with the following additions: EDH = Edoras High; HH $=$ Hatton High; NCSB $=$ North Celtic Sea Basin; NHB = North Hatton Basin; PB Porcupine Basin; $\mathrm{PH}=$ Porcupine High; PHB = possible basin on Porcupine High; R1-R3 = possible basins on Rockall High; RB = Rockall Basin; RH = Rockall High; SCSB = South Celtic Sea Basin; SDR = seaward-dipping reflectors; SHB = South Hatton Basin; SHL = South Hatton Lineament; WAB = Western Approaches Basin.

Fig. 5 (a) Thickness of crystalline crust and (b) depth to Moho in the optimised model. Heavy contours are at $10 \mathrm{~km}$ intervals. CGFZ $=$ Charlie Gibbs Fracture Zone; ETR $=$ East Thulean Rise; HB = Hatton Basin; PB = Porcupine Basin; RB = Rockall Basin.

Fig. 6 (a) Observed and (b) calculated free-air gravity fields over the Irish Continental Shelf. Colour shaded-relief images with illumination from the north (same colour scale and imaging parameters applied in both maps). The observed field was compiled by the Irish Petroleum Affairs Directorate from sources including their own surveys, the Irish National Seabed Survey and satellite-derived data (Sandwell and Smith, 1997). HB = Hatton Basin; GH = gravity high within Rockall Basin; $\mathrm{PB}=$ Porcupine Basin; $\mathrm{RB}=$ Rockall Basin; $\mathrm{SHL}=$ South Hatton Lineament.

Fig. 7 Deep structure beneath the RAPIDS 33 seismic profile, comparing a section through the 3D model (top two panels) with the seismic interpretation of Mackenzie et al. (2002) (bottom panel). 3D model interfaces are superimposed as heavy black lines on the seismic model. Numbers in the bottom panel are P-wave velocities in $\mathrm{km} / \mathrm{s}$.

Fig. 8 (a) Observed and (b) calculated magnetic field over the Irish Continental Shelf. Colour shaded-relief images with illumination from the north (same colour scale and imaging parameters applied in both maps). The observed field was compiled by the Irish Petroleum Affairs Directorate from sources including their own surveys, the Irish National Seabed Survey and the GAMMAA5 compilation (Verhoef et al., 1996). The first reversed polarity interval in the oceanic crust (C33R) is clearly imaged in the observed data and its location is shown on the modelled version (which does not include magnetic reversals). BVRS $=$ Barra Volcanic Ridge System; HB = Hatton Basin; $\mathrm{MH}=$ magnetic high within Hatton Basin; $\mathrm{PB}=$ 
Porcupine Basin; PVRS = Porcupine Volcanic Ridge System; RB = Rockall Basin; SHL = South Hatton Lineament.

Fig. 9 (a) Observed and (b) calculated pseudogravity field over the southeast Rockall Porcupine - Goban Spur area. C33R, C34N = oceanic crust of chron indicated; COB = continent-ocean boundary (purple line); IS = possible magnetic expression of the Iapetus Suture; PB = Porcupine Basin; PH = Porcupine High; PHB = sedimentary/metasedimentary body on Porcupine High suggested by an observed pseudogravity low; RB = Rockall Basin; WAM = Western Approaches Margin seismic profile (BIRPS and ECORS, 1986). 


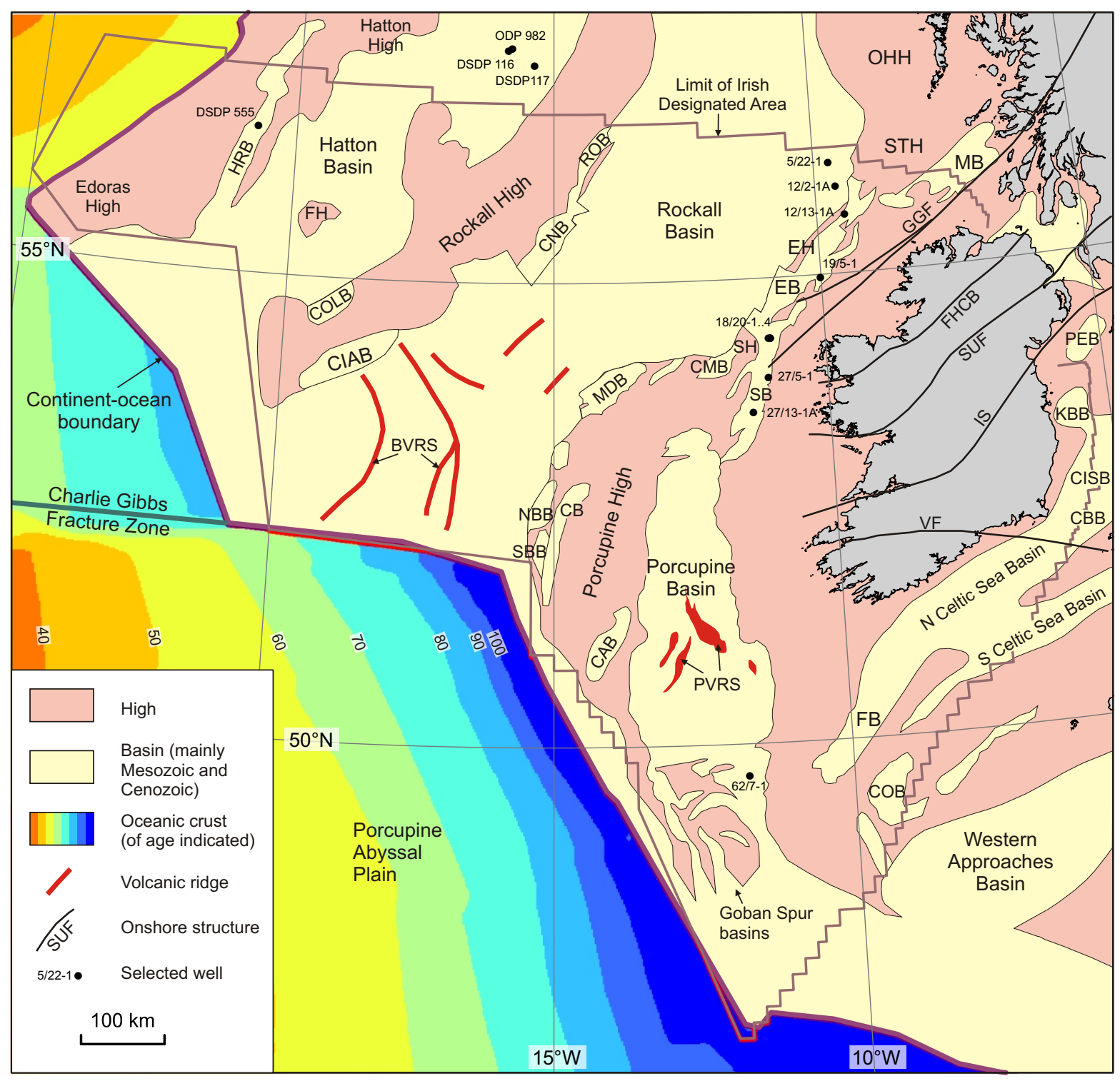

Kimbell et al. Fig. 1 

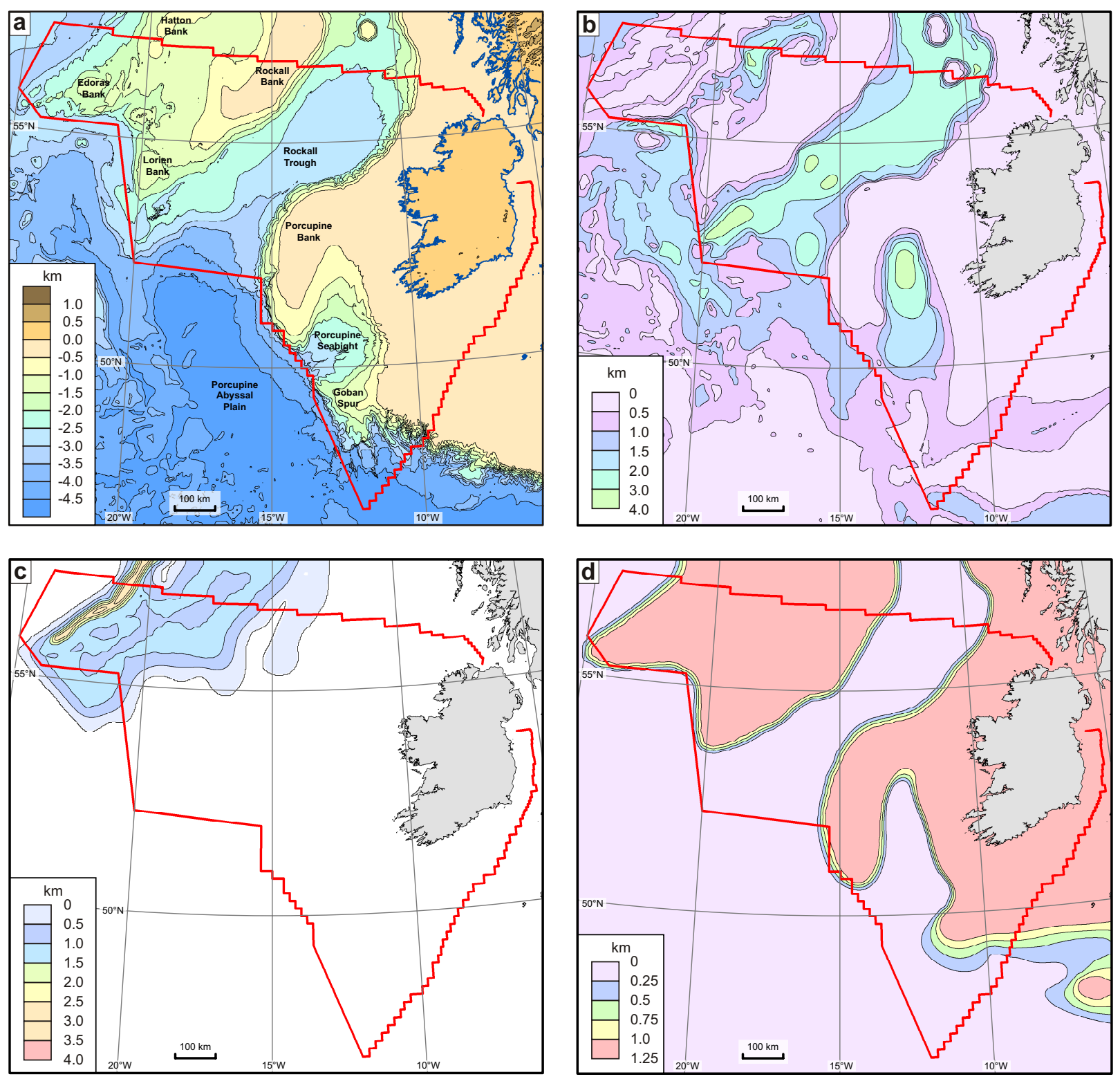

Kimbell et al. Fig. 2 

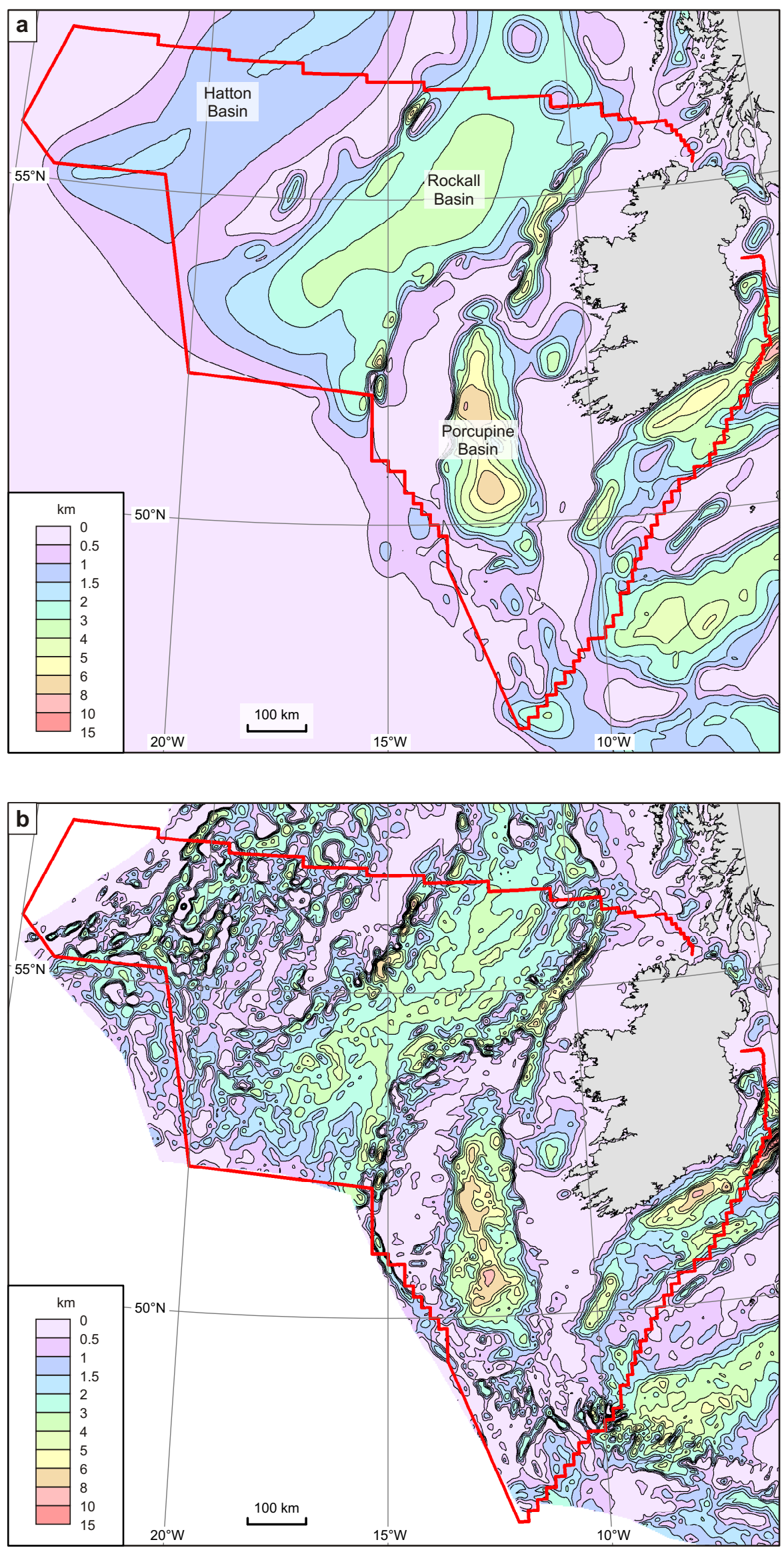

Kimbell et al. Fig. 3 


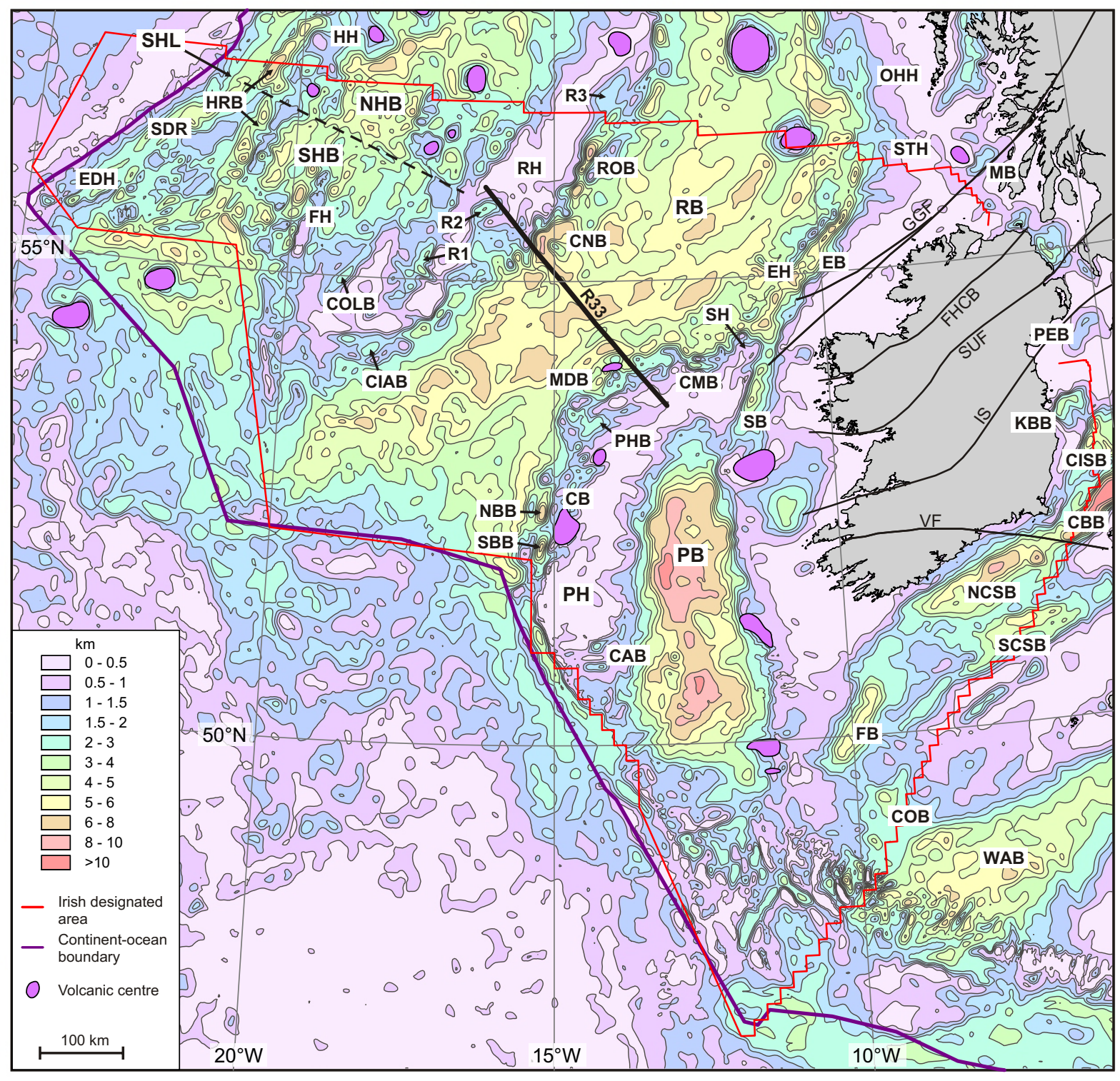

Kimbell et al. Fig. 4 

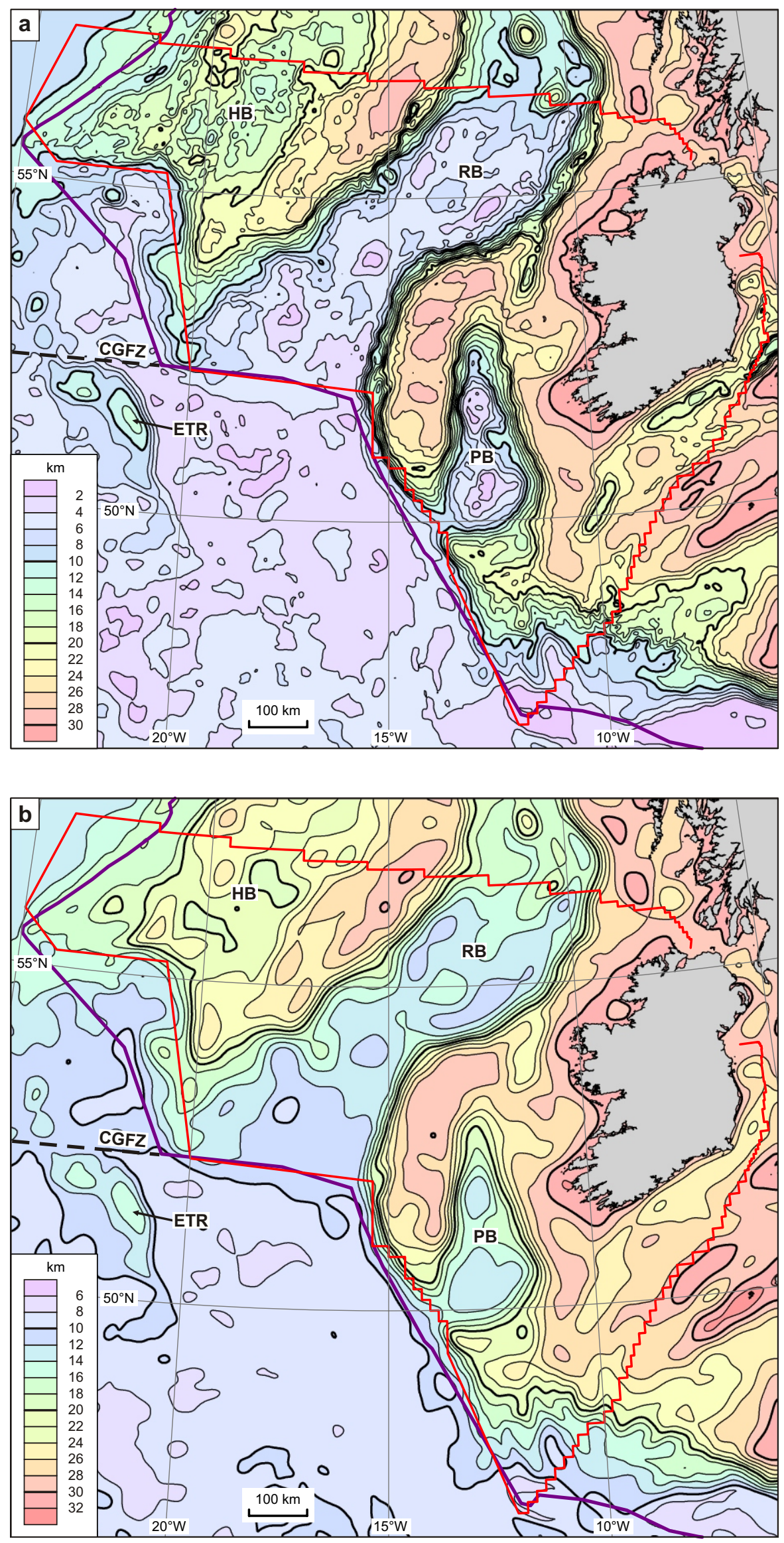

Kimbell et al. Fig. 5 

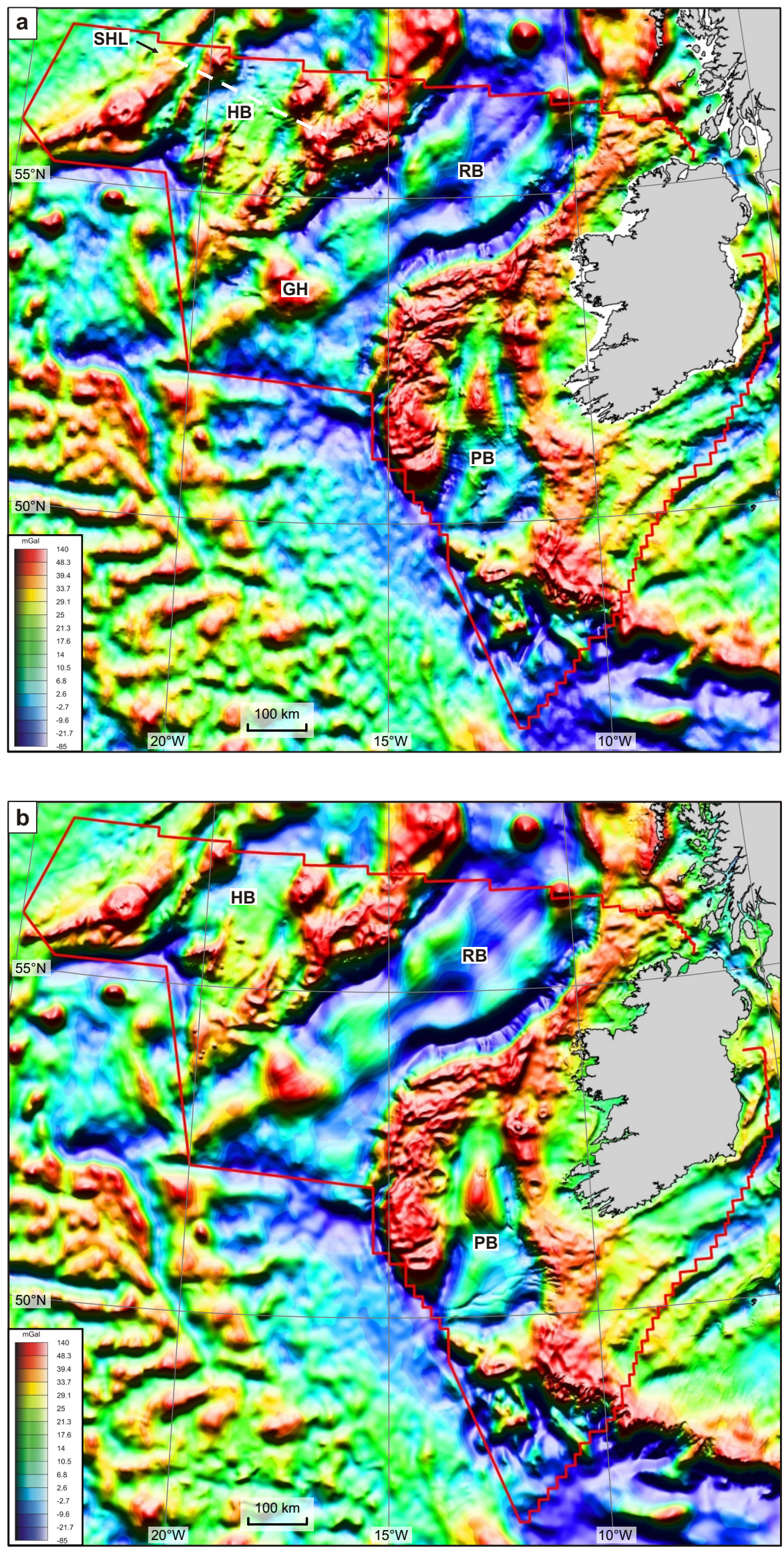

Kimbell et al. Fig. 6 

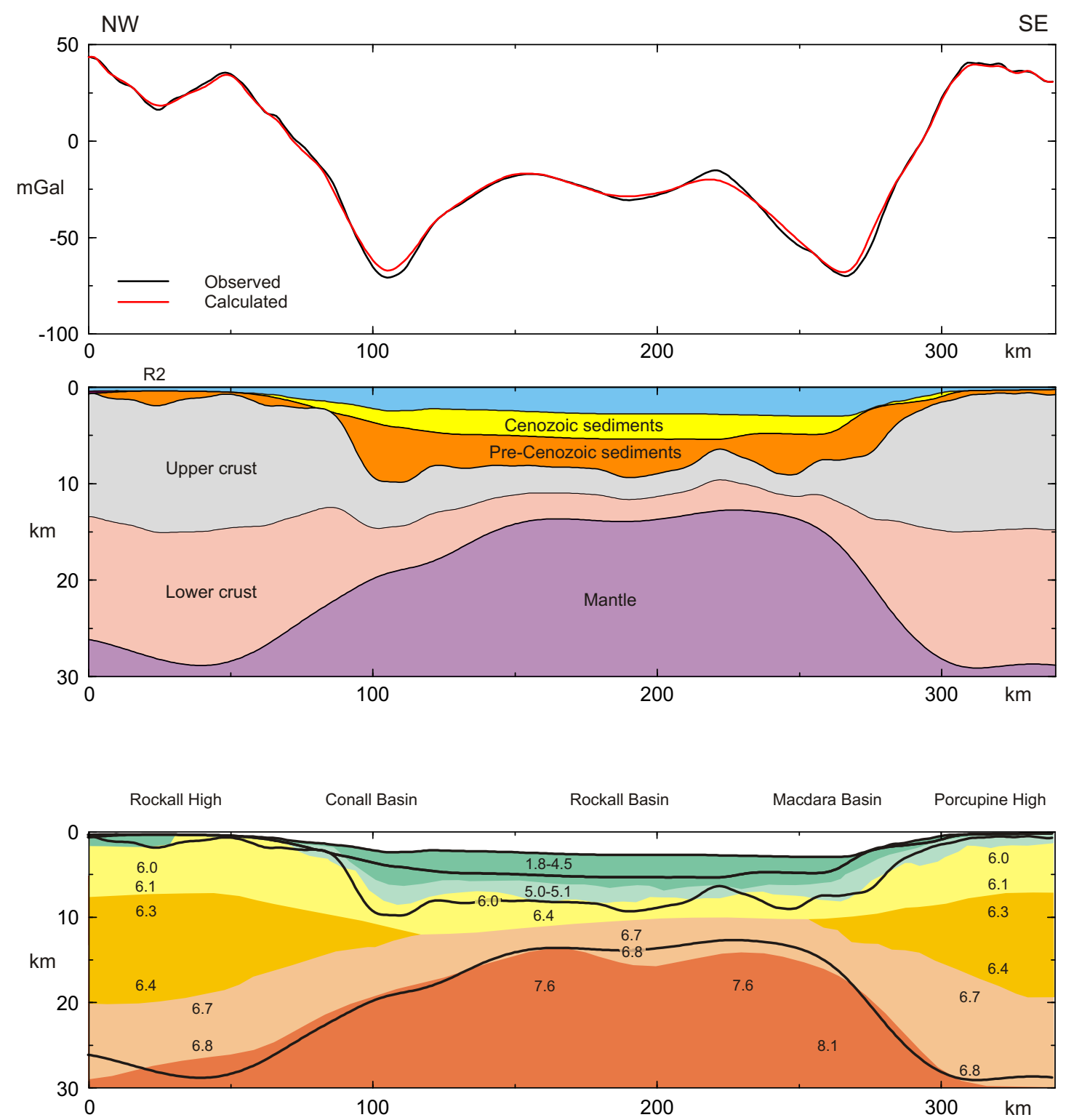

Kimbell et al. Fig. 7 

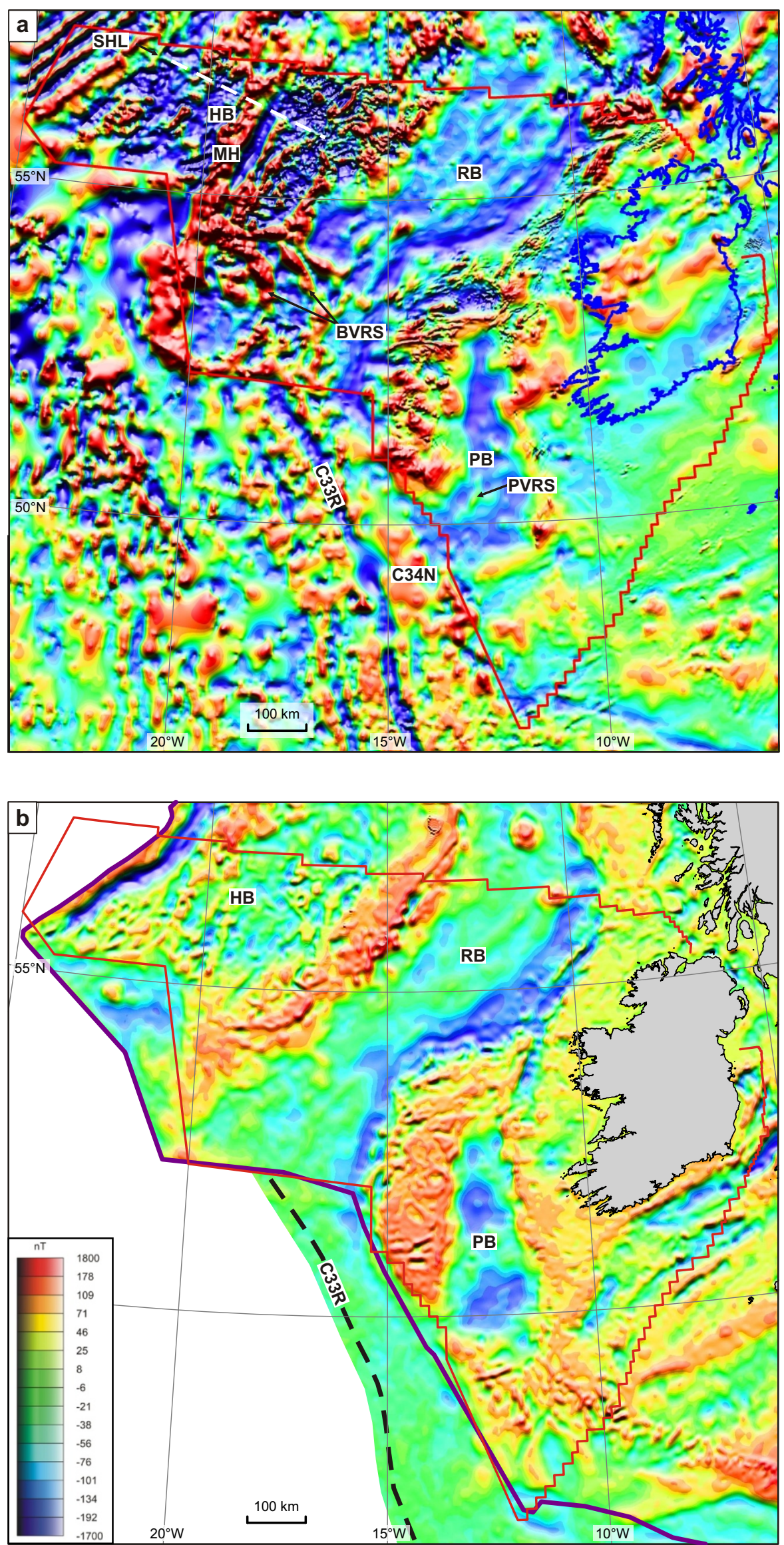

Kimbell et al. Fig. 8 


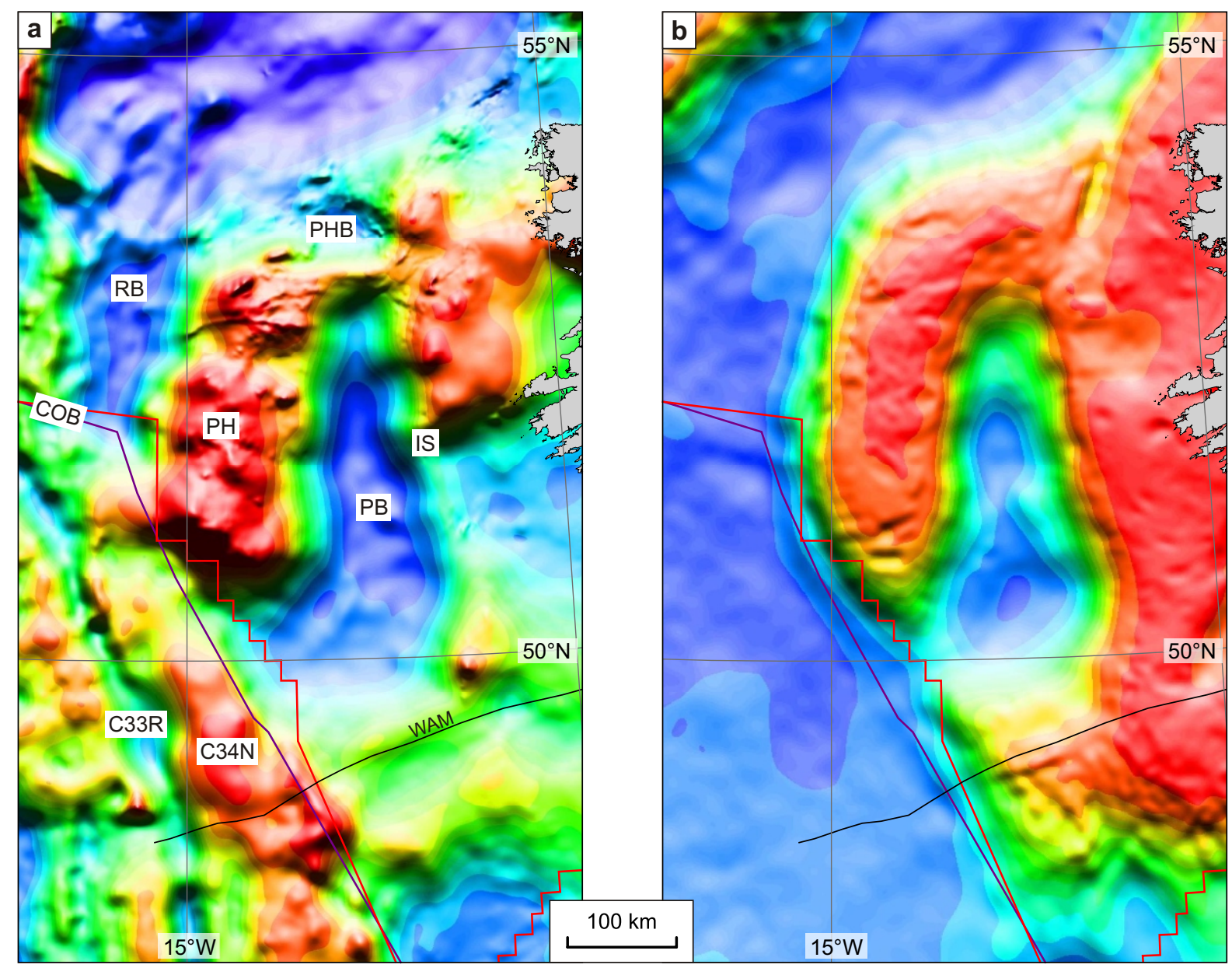

Kimbell et al. Fig. 9 